\title{
REMODELACIONES EN EL HOSPITAL DE BARRANTES (1767-1800). CABILDO, CIRUJANOS, POBRES, SOLDADOS, QUADRAS Y CAMAS
}

\author{
Francisco J. Sanz de la Higuera \\ I.E.S. Torreblanca, Sevilla
}

RESUMEN: El hospital de San Julián y San Quirce u hospital de Barrantes fue reedificado en 1747-1750 sobre la base del primitivo edificio del siglo XVII. Ya incluso en ese momento se plantearon algunos problemas estructurales y de espacio ambulatorio, que, posteriormente, harían imprescindibles nuevas actuaciones arquitectónicas y adoptar medidas tendentes a albergar, de una manera equilibrada y sostenible, a las poblaciones enfermas, fueran civiles o militares. La llegada de múltiples y muy numerosos contingentes de tropa enervó, sobre todo en los últimos años del siglo, la ya tensa situación interna y los problemas financieros y contables.

Palabras clave: Hospital, Barrantes, obras de remodelación, militares.

ABSTRACT: St Julian and St Quirce Hospital or Barrantes Hospital was rebuilt in $1747-1750$ on the base of the former building of the $17^{\text {th }}$ Century. Even at that moment, some problems about structure and space were set out, problems which, later on, would make indispensable new architectonic works and measures to house, in a sensible and sustainable way, the sick population, either civil or military. The arrival of many and big army groups, made worse, especially in the last years of the Century, the internal situation, that was already tense, as well as the financial and accountant problems.

Keywords: Hospital, Barrantes, rebuild site, military.

\section{Introducción, fuentes documentales y bibliografía}

El morbo gálico, la sífilis, traía por la calle de la amargura a los profesionales de la salud de Burgos, a los responsables del Cabildo catedralicio y del pro- 
pio Hospital de Barrantes y, por supuesto, a los más afectados, en especial a los soldados de los diferentes regimientos acantonados en la ciudad y a los paupérrimos enfermos civiles contagiados o no de la terrible enfermedad. De hecho, como ya demostramos en un trabajo anterior ${ }^{1}$, las renovadas instalaciones hospitalarias de Barrantes tuvieron -esa era en gran parte la razón de su existenciacomo principal cometido remediar, o al menos paliar, las patologías clínicas que se derivaban de tan temible enfermedad y, en especial, en un breve pero intenso segmento de su historia, de la tropa del Regimiento de Inválidos de Cataluña (1749-1753). El último cuarto del siglo XVIII y los primeros compases del Ochocientos estuvieron preñados, también, de múltiples inquietudes como telón de fondo, con crisis económicas galopantes, sucesos epidémicos extraordinarios y acontecimientos bélicos onerosos devenidos desde suelo francés. El inflacionario incremento de soldadesca en la ciudad de Burgos puso en difíciles aprietos al Hospital de Barrantes y a sus gestores.

La erección del nuevo edificio del hospital San Julián y San Quirce ${ }^{2}$, entre 1748 y $1752^{3}$, adoleció de importantes defectos estructurales. Aunque se introdujeron muchas mejoras con respecto al edificio anterior ${ }^{4}$, lo cierto es que se cometieron bastantes errores y, a la postre, se pueden calificar de chapuza tanto las dimensiones como los diseños interiores del nuevo hospital ${ }^{5}$. Llegadas

1. SANZ de la HIGUERA, F. (2005): “Obras en Barrantes (1747-1750)”, en Boletín de la Institución Fernán González (BIFG), 230, Burgos, pp. 115-147.

2. Llamado por el "vulgo" (sic) hospital de Barrantes en recuerdo de su mecenas, don Juan de Barrantes, el canónigo que en el siglo XVII propuso su creación, definió los propósitos de su existencia y financió su construcción.

3. Sirva esta llamada para reivindicar el excelente trabajo de ZAPARAíN YÁÑEZ, M. J. (2000): "La aportación de los maestros vascos a la arquitectura barroca castellana. Nuevos datos sobre la obra de Domingo de Ondátegui", en Ondare, 9, Revisión del arte barroco, Bilbao, pp. 425-433, a cuya lectura he accedido gracias a la amabilidad de su autora, magnífica profesional y agradable amiga, obra que, por ignorancia y desconocimiento, no cité en el artículo sobre las obras en Barrantes en 1747-1750, muestra evidente de mi torpeza y "miopía" bibliográfica.

4. El primer edificio del Hospital de San Julián y San Quirce estaba obsoleto y deficitario en muchos aspectos desde hacía bastantes años, como lo demuestra el que desde la década de los 30 del Setecientos se viniera debatiendo sobre la necesidad de construir un nuevo inmueble más acorde con los tiempos. El tiempo pasaba y únicamente la llegada a la ciudad del Regimiento de Inválidos de Cataluña, y posteriormente, otras unidades militares, exigieron la erección de un renovado hospital.

5. Planos y descripción de las estancias de hospitales españoles en RIERA, J. (1975): Planos de hospitales españoles del siglo XVIII existentes en el Archivo General de Simancas, Valladolid -este libro, aparentemente desaparecido en el Departamento de Historia Moderna de la Universidad de Sevilla, finalmente fue colocado en el lugar que le correspondía y pudo ser consultado por los investigadores-; PARRILLA HERMIDA, M. (1973): "Apuntes históricos sobre la hospitalización castrense en La Coruña: Historia de su hospital militar", en Asclepio, 25, pp. 179-252; FALCÓN PÉREZ, M. I. (1980): "Sanidad y beneficencia en Zaragoza en el siglo XV", en Aragón en la Edad Media, 3, Zaragoza, pp. 183-226, cuyo apartado "Descripción del establecimiento" constituye, a mi juicio, un magnífico ejercicio de sencillez preñada de incon- 
horas de agobio por el incremento experimentado en la demanda exterior, en especial por parte de las tropas acantonadas en la ciudad, se hacía imprescindible efectuar remodelaciones notables en su distribución interior, horizontal y vertical, e implementar nuevos espacios ambulatorios para los enfermos y enfermas, pero siempre desde la limitación impuesta por el edificio ya construido y la necesidad de mantener un cierto equilibrio entre los civiles y los militares. Algunos se vieron sacudidos de una manera muy honda y traumática. Las voraces exigencias de camas y de recursos humanos y materiales por parte de los Ejércitos y del Monarca ${ }^{6}$ iban a ocasionar, como también estaba ocurriendo en los otros hospitales de la ciudad, un desbordamiento persistente e insostenible de las "estanzias de Hospittalidad" de soldados, en detrimento de la asistencia quirúrgica -"Zirujía"- y médica -"Unziones"- a los vecinos y vecinas sin encuadramiento castrense. La marabunta militar no tenía escrúpulos a la hora de resolver sus problemáticas, y no sólo las sanitarias, aunque fuera pasando, literalmente, por encima de quien fuese.

Para la realización de esta reconstrucción histórica me he zambullido en las Actas Capitulares del Cabildo Catedral de Burgos ${ }^{7}$ y en los fondos del Hospital de San Julián y San Quirce (Barrantes), ubicados también en el citado ACCB. Lamentablemente se han extraviado los volúmenes confeccionados para anotar los ingresos desde 1730 si bien disponemos de un extraordinario "Libro de enfermos que se reciben para su curación y remedio en Barrantes" (1699$1730)^{8}$. No hemos de olvidar, a la postre, que el hospital de San Julián y San Quirce era una institución dependiente, de patronato, del Cabildo catedralicio de Burgos y estaba sujeto, además, a las problemáticas asistenciales, clínicas y

mensurable brillantez; ALONSO de PORRES FERNÁNDEZ, C. (1997): "El hospital de Santa Catalina de la ciudad de Burgos", en Memoria Ecclesiae, Oviedo, tomo X, pp. 489-499. Este hospital también hubo de ser reconstruido como consecuencia del maltrato y la ruina a que quedó abocado tras el paso por sus instalaciones de múltiples soldados de caballería, al ser convertido transitoriamente en cuartel durante la guerra de Sucesión. "La delicada situación del edificio -señala el autor- no resistió el trato brusco de la tropa". También en GEA ARIAS, A. y LÓPEZ GUERRERO, R. M.. (1997): "De la calidad y circunstancias de los pobres que se recibían en el hospital de Guadix y su tratamiento de ellos", en Memoria Ecclesiae, Oviedo, tomo X, pp. 545-554.

6. Al fin y al cabo, ellos si dejaban una substancial contribución económica en las arcas del Hospital, entre 4 y 5 reales por estancia de soldado, aportación que los paupérrimos civiles no estaban en condiciones de realizar. En el hospital de Barrantes, llegó a ser en el momento más álgido del siglo XVIII (1793) de un 38.2\% del total del "Cargo" computado por los administradores de la institución.

7. En adelante citadas como A(rchivo) del C(abildo) de la C(atedral) de B(urgos), A(ctas) $\mathrm{C}($ apitulares). Sus gruesos y preñados L(ibros) de R(egistro) están afortunada y dichosamente completos para todo el Setecientos, circunstancia que posibilita un rastreo sistemático, de tercer nivel -según la brillante expresión de Chaunu- y una búsqueda intensiva e intensa en sus múltiples folios de los aconteceres y vicisitudes del Cabildo catedralicio burgalés.

8. ACCB. Barrantes. Libro 67 (1699-1712) y Libro 68 (1712-1730). 
financieras y fórmulas resolutivas adoptadas en otros establecimientos similares en el siglo XVIII castellano?.

Como fórmula de contraste se traerán a colación las estancias de soldados en otros hospitales de la ciudad de Burgos, en especial el Hospital del Rey, dependiente del Real Monasterio de Las Huelgas ${ }^{10}$, y el hospital de Nuestra Señora de la Concepción, cuya titularidad gozaba el Concejo burgalés -léase Ayuntamiento- ${ }^{11}$. Es imposible analizar las vicisitudes de Barrantes desde la ignorancia de lo que, simultáneamente, estaba ocurriendo en los demás centros hospitalarios cercanos. ¿Las problemáticas y vicisitudes de que estaba aquejado el hospital de Barrantes eran únicamente debidas a su especial configuración o compartía con otros establecimientos sanitarios circunstancias más o menos similares? ¿El hospital de Barrantes, como centro asistencial bajo patronato catedralicio, se asemeja en sus perfiles ordinarios o extraordinarios a los quehaceres de otras instituciones repartidas por el territorio hispánico o sus circunstancias son particularmente intransferibles y genuinas?

La respuesta a esta y otras interrogantes se aborda con el auxilio de un acervo bibliográfico que nos acompañará constantemente, imprescindible herramienta de inmersión en el panorama hospitalario de la segunda mitad del Setecientos y los primeros compases del siglo XIX. Descuellan, de entre la inmensa nómina de investigadores que nos han brindado sus reflexiones sobre esta problemática, los trabajos de Foucault, Parrilla Hermida, Sánchez Granjel, Riera Palmero, Marcos Martín, Carasa Soto, Carmona García, Palomares Ibáñez, Maza Zorilla, López Gómez, Menéndez Navarro y Rodríguez Ocaña, Anes

9. Véase a este respecto los análisis aparecidos en, por ejemplo, BETHENCOURT, A. de (1971-1972): "El hospital de San Lázaro, el doctor Cubas y el Cabildo de Gran Canaria (16471657)", en Revista de Historia Canaria, 169, pp. 101-109; LÓPEZ MORA, F. (1992): Pobreza y asistencia caritativa en el Reino de Córdoba: los hospitales de Jesús Nazareno (a fines del siglo XVIII), Córdoba, pp. 31-34; GIL PECES RATA, F. (1997): "Hospitales catedralicios en Sigüenza", en Memoria Ecclesiae, Oviedo, tomo X, pp. 341-3247; FATJÓ GÓMEZ, P. (1985-1986): "La beneficencia eclesiástica en la Barcelona del XVIII: la Pía Almoina, 1655-1669", en Estudis, Revista de Historia Moderna, 12, Valencia, pp. 71-96 o QUINTANA ANDRÉS, P. C. (2003): "Grupos urbanos y asistencia social: el hospital de San Martín de Las Palmas en el Seiscientos", en Vegueta, 7, Las Palmas de Gran Canaria, pp. 41-64. Véanse también, RAFAT i SELGA, J. (1991): "Notes sobre militars a I'Hospital de Manresa (segles XVIII i XIX)", en Gimbernat, 15, pp. 237-250; GÓMEZ PÉREZ, C. (1988): "Los hospitales militares en el siglo XVIII", en Temas de Historia Militar, I/ Congreso de Historia Militar, vol. 2, Zaragoza, pp. 325-337; PITA MOREDA, M. T. (1984): "Los hospitales andaluces y el ejército de América", en TORRES RAMÍREZ, B. y HERNÁNDEZ PALOMO, J. J. (Eds.), Andalucía y América en el siglo XVIII, IV Jornadas de Andalucía y América, vol. I, La Rábida, pp. 349-378 y BACHALET, N. (2000): L'Hôpital General de Nantes: le sanitat. Le traitament de la pauvreté à l'epréuve des nécessitées économiques, XVIle-XVIIle siècles, Rennes, I.

10. A(rchivo) G(eneral) de P(alacio) -Madrid-. Patronatos. Hospital del Rey.

11. A(rchivo) M(unicipal) de B(urgos). Hospital de Nuestra Señora de la Concepción. 
Fernández, Quevedo y Zaldúa, Perdiguero Gil, Martín García y Pérez Álvarez, Sánchez Sánchez ó Alzate Echeverri ${ }^{12}$.

12. FOUCAULT, M. (1985): "La política de la salud en el siglo XVIII", en Saber y verdad, Madrid, pp. 89-106; PARRILLA HERMIDA, M. (1973): "Apuntes históricos sobre la hospitalización castrense ...", en Asclepio, 25, Madrid, pp. 179-252, (1972): "Un hospital militar en 1716", en Medicina e Historia, 15, Barcelona, pp. 16-25 y (1964): El hospital militar español de Malinas en los siglos XVI y XVII, Madrid; SÁNCHEZ GRANJEL, J. L. (1979): La medicina española en el siglo XVIII, Salamanca; RIERA PALMERO, J. (1975): Planos de hospitales españoles del siglo XVIII existentes en el Archivo General de Simancas, Valladolid, (1974-1975): "Organización hospitalaria militar en la España ilustrada (Las "Ordenanzas" de 1739)", en Asclepio, 26-27, Madrid, pp. 115134, (1982): Ordenanzas y asientos de hospitales militares en España (sig/o XVIII), Valladolid y (1982): Anatomía y cirugía española del siglo XVIII, Valladolid; MARCOS MARTíN, A. (1985): Economía, sociedad y pobreza en Castilla: Palencia, 1500-1812, Palencia, tomo I, pp. 350-358 y tomo II, pp. 554-690; CARASA SOTO, P. (1983): "Beneficencia en Castilla y León. Transformaciones del sistema hospitalario entre 1750-1900", en El pasado histórico de Castilla y León, III, Burgos, pp. 299-326, (1984): "Crisis y transformación de la beneficencia de Antiguo Régimen. Aproximación al sistema hospitalario de La Rioja entre 1700 y 1900", en Cuadernos de Investigación Histórica, 10/1, Logroño, pp. 7-26; CARMONA GARCÍA, J. I. (1979): El sistema de hospitalidad pública en la Sevilla del Antiguo Régimen, Sevilla y (1981): "La quiebra de las instituciones benéficas como reflejo de la crisis económica del siglo XVIII", en Archivo Hispalense, 196, Sevilla, pp. 3-27; PALOMARES IBÁÑEZ, J. M. (1975): La asistencia social en Valladolid: el hospital de pobres y la Real Casa de misericordia (1724-1847), Valladolid; MAZA ZORRILLA, E. (1982): "Pobreza y hospitalidad pública en la ciudad de Valladolid a mediados del siglo XVIII", en Investigaciones Históricas, 3, Valladolid, pp. 33-75 y (1985): Valladolid: sus pobres y la respuesta institucional (1750-1900), Valladolid; LÓPEZ GÓMEZ, J. M. (1997): “La asistencia sanitaria a militares enfermos en el Burgos del último tercio del siglo XVIII", en BIFG, 215, Burgos, pp. 245-272, (1996): Cirugía ilustrada en Burgos: la figura y la obra de José Victoriano Gómez (1773-1819), Burgos, (1993): "Los médicos del Cabildo catedralicio de Burgos en el siglo XVIII", en BIFG, 207, Burgos, pp. 411-448, (1996): Salud y enfermedad en el Burgos de la segunda mitad del siglo XVIII, Burgos y (1999): "Los profesionales sanitarios de la ciudad de Burgos en 1740", en BIFG, 218, Burgos, pp. 20-31; MENÉNDEZ NAVARRO, A. y RODRÍGUEZ OCAÑA, E. (2005): "Salud, trabajo y medicina en la España ilustrada", en Archivo de Prevención de Riesgos Laborales, 8/1, Madrid, pp. 4-13; RODRÍGUEZ OCAÑA, E. (1987-1988): "El resguardo de la salud. Organización sanitaria española en el siglo XVIII", en Dynamis, 7-8, Madrid, pp. 145-170; ANES FERNÁNDEZ, L. (2000): Pobreza y beneficencia en Asturias en la segunda mitad del siglo XVIII, Oviedo; QUEVEDO VÉLEZ, E. y ZALDÚA T., A. (1992): "Antecedentes de las reformas médicas del siglo XVIII y XIX en el nuevo Reino de Granada. Una polémica entre médicos y cirujanos", en LAFUENTE, A. y SALA CATALÁ, J. (Eds.), Ciencia colonial en América, Madrid, pp. 192-218; PERDIGUERO GIL, E. (2002): "“Con medios humanos y divinos": la lucha contra la enfermedad y la muerte en Alicante en el siglo XVIII", en Dynamis, 22, Madrid, pp. 121-150 y el citado junto con BERNABEU, J. (1995): "La asistencia médica pública en el Alicante del siglo XVIII: Ios médicos de la ciudad", en Canelobre, 29-30, Alicante, pp. 165-176; MARTíN GARCÍA, A. y PÉREZ ÁLVAREZ, M. J. (2007): "Hospitalidad y asistencia en la provincia de León a finales del Antiguo Régimen (1728-1896)", en Dynamis, 27, pp. 157-185; SÁNCHEZ SÁNCHEZ, A. (2000): La beneficencia en Ávila: actividad hospitalaria del Cabildo Catedralicio (Siglos XVI-XIX), Ávila y ALZATE ECHEVERRI, A. M. (2009): "Devociones políticas y oratoria salubrista. Sobre un plan de reforma hospitalaria en la Nueva Granada (1790)", en http://historiacritica. uniandes. edu. co/ datos /pdf /data/H_Critica_23/04_H_Critica_23.pdf y (2008): "Militares, marineros y pobres enfermos. Contribución a la historia del hospital San Juan de Dios de Cartagena de Indias (siglo XVIII)", en Asclepio, 60/1, Madrid, pp. 203-236. 
La segunda mitad del XVIII estuvo marcada por un proceso generalizado de conflicto y acelerada crisis de los sistemas hospitalarios del Antiguo Régimen. El hospital de Barrantes no fue una excepción. En la práctica, aunque no fue erigido para ello en principio, el hospital de San Julián y San Quirce se comportaba como un asentista funcional para los Reales Ejércitos borbónicos ${ }^{13}$. Aunque no existía un contrato específico, el Acuerdo de $1769^{14}$ vino a dar rango legal a la asistencia que los cuatro hospitales burgaleses firmantes daban a los militares, en especial la tropa, cada uno con sus patologías características y diferenciales. Además, por supuesto, de las intervenciones, tratamientos y medicinas, los hospitales daban a sus pacientes militares alimentos, cama, ropa, leña, luz y utensilios a cambio de una cantidad fija por la estancia de cada soldado, que en la segunda mitad del Setecientos osciló entre los 4 y los 5 reales/día. Tal asignación, descontados los costes de intervención y mantenimiento, daban al asentista -en este caso a la contabilidad del hospital de Barrantes- un pequeño margen de beneficio por cada militar asistido y día. En determinados momentos de mayor morbilidad o de grave conflicto bélico, la suma total de estancias supuso para algunos asentistas ingresos extraordinariamente considerables ${ }^{15}$. La abundante llegada de soldadesca a las instalaciones de los hospitales generó, no obstante, profundos desequilibrios espaciales, conflictos humanos y problemas financieros que perturbaban profundamente la cotidianeidad de los establecimientos hospitalarios. La asistencia a los pobres paisanos era gratuita. La

13. No discuto, en absoluto, con esta expresión, asentista funcional, las acertadas palabras del doctor LÓPEZ GÓMEZ cuando señala "Estos convenios no eran propiamente "asientos", pues en puridad no existía en ellos la figura del asentista, sino que eran los diferentes administradores seglares o eclesiásticos de los centros asistenciales los que también a cambio de una cantidad prefijada por militar enfermo y día se comprometían a albergar en sus respectivos centros hasta un número determinado de ellos", en (1997): "La asistencia sanitaria a militares enfermos...", en BIFG, 215, Burgos, pp. 248. Véase igualmente la magnífica aportación de LÓPEZ GÓMEZ, J. M. (1990): Salud pública y medicina en Mérida (1700-1833), Mérida, pp. 244-372 y LINDEMANN, M. (2001): Medicina y sociedad en la Europa Moderna, 1500-1800, Madrid.

14. Dispongo de las versiones del Acuerdo de 1769 custodiadas en el Archivo Municipal de Burgos (AMB) por lo tocante al hospital de Nuestra Señora de la Concepción -AMB. Hospital de la Concepción, Legajo 822 y Beneficencia, Legajo 14- y en el Archivo General de Palacio (AGP) en lo relativo al Hospital del Rey - AGP. Patronatos. Hospital del Rey. Caja 131, Expediente 1. Es, a mi entender tremendamente significativa la rotulación con que se archivaron en su origen cada uno de ellos. En el hospital municipal se señala de una manera ramplona, cortante, cicatera y contestataria "Real orden $p^{a}$ qe se recivan Soldados En el Hospital de la Concepción. 1769" -Leg 10. N $^{\circ}$ 17-. El custodiado en el AGP fue mucho más plástico y descriptivo. "Testimonio de un Convenio entre el Secretario del Ministerio de la Guerra con asistencia del Intendente de la Ciudad de Burgos y el Comisario de Guerra de ella, sobre el número de enfermos que cada Hospital debía admitir con distinción de enfermedades. Su fecha en Aranjuez á 5 de Junio de 1769" -Gobierno. Legajo 10, Atado 30, Núm. 1".

15. LÓPEZ GÓMEZ, J. M. (1997): “La asistencia sanitaria a militares enfermos en el Burgos ...", en BIFG, 215, Burgos, pp. 247. 
Hacienda Real pagaba 4 reales/día por estancia de soldado. Los administradores seglares (mayordomo) y eclesiásticos no le hicieron asco a los dineros del Rey, dado que desde el 19 de enero de 1749 estaban obligados a atender indefectiblemente a los militares enfermos en los hospitales de Castilla ${ }^{16}$.

Los Reales Ejércitos no disponían en Burgos de un hospital militar propio. De hecho, no existía ninguno en toda esa Capitanía General ${ }^{17}$. Los mandos de los Regimientos que se acantonaron en Burgos en la segunda mitad del siglo XVIII pretendieron, en la práctica y de forma tácita o explícita, convertir algunos, o todos, los hospitales de la ciudad en hospitales al servicio de sus tropas, no sólo en lo habitual sino, sobre todo, en los momentos más álgidos de epidemias catastróficas o de conflictos abiertos, en especial contra Francia, períodos en que los cuidados facultativos, dietéticos y farmacológicos eran urgentes e imprescindibles ${ }^{18}$.

Como han señalado el doctor López Gómez y Sanz de la Higuera ${ }^{19}$, y descubrimos, también, la asistencia a las tropas enfermas en múltiples ocasiones durante la primera mitad del siglo. El "campo de batalla" asistencial estaba sembrado de antemano. En los "Libros de enfermos que se reciben para su curación y remedio en Barrantes" (1699-1730) se descubre la presencia de las tropas del Regimiento de Milicias de la provincia, el Regimiento de Asturias o el Regimiento de la Reina ${ }^{20}$. La reedificación de Barrantes, ha sostenido $-y$ sostiene- Sanz de la Higuera vino impelida por la llegada a Burgos, en 1749, del Regimiento de Inválidos de Cataluña, unidad militar que arribó a la ciudad para quedarse, salvo que otra fuera la estrategia de gobierno, por expreso deseo del marqués de la Ensenada, quien cambió el cuartel del citado Regimiento en 1753 para traer a otros a partir de ese momento. El Cabildo de la Catedral y los gestores de Barrantes vieron negocio y los mandos militares la virtualidad de cubrir sin excesivos problemas la atención quirúrgica y facultativa de sus tropas ${ }^{21}$.

16. Véase la "Instrucción y Ordenanza" redactada por Ustáriz, custodiada en el Archivo General de Simancas (AGS). Guerra Moderna (GM). "Instrucción y Ordenanza que debe observarse en los Hospitales de Castilla para la curación de los enfermos militares", Legajo 2417 (Salamanca, 19 de enero de 1749).

17. AGS. GM. Legajo 2460(1773).

18. LÓPEZ GÓMEZ, J. M. (1997): "La asistencia sanitaria a militares enfermos...", en BIFG, 215, Burgos, pp. 247.

19. LÓPEZ GÓMEZ, J. M. (1997): "La asistencia sanitaria a militares enfermos...", en BIFG, 215, Burgos, pp. 245-272; SANZ DE LA HIGUERA, F. J. (2005): "Obras en Barrantes (17471750)", en BIFG, 230, Burgos, pp. 115-147 y (2002): "Alojamiento de tropas en Burgos a mediados del siglo XVIII. Cuarteles, alquileres y hospitales para el Regimiento de Inválidos de Cataluña (1748-1753)", en Actas de las XI Jornadas Nacionales de Historia Militar, Milicia y Sociedad ilustrada en España y América (1750-1800), tomo I, Sevilla, pp. 335-360. Véase igualmente MAZA ZORRILLA, Passim, pp. 112 y 169-177.

20. ACCB. Barrantes. Libro 67 (1699-1712) y Libro 68 (1712-1730).

21. SANZ DE LA HIGUERA, F. J. (2005): "Obras en Barrantes...", en BIFG, 230, Burgos, pp. 115-147, LÓPEZ GÓMEZ, J. M. (1997): "La asistencia sanitaria a militares enfermos...", en 
“El hospital -señala el siempre cáustico Foucault- aparece como una estructura anticuada. Fragmento de espacio cerrado sobre sí mismo, lugar de internamiento de hombres y de enfermedades, arquitectura solemne pero desmañada que multiplica el mal en su interior sin impedir que se difunda en el exterior, el hospital es más un foco de muerte para las ciudades en donde está situado que un agente terapéutico para toda la población. (...) En el interior del espacio urbano (...) constituye una mancha sombría. Y para la economía un peso inerte puesto que dispensa una asistencia que no permite la disminución de la pobreza, sino, como máximo, la supervivencia de ciertos pobres y por tanto el crecimiento de su número, la prolongación de sus enfermedades, la consolidación de su mala salud con todos los efectos de contagio que de ello pueden derivarse" ${ }^{\prime 22}$. Es probable que el filósofo francés no conociera de primera mano la existencia del hospital de Barrantes pero, como se va a descubrir en las próximas páginas, el párrafo anterior resume fielmente y con toda crudeza la realidad habitual de dicho hospital y de los otros grandes centros asistenciales de la ciudad.

Para la masa humana, para los "pecheros" e individuos del estamento general, fueran paisanos, fueran soldadesca, el lazareto, aunque estuviera disfrazado formalmente de hospital, era la única solución para el tratamiento de sus enfermedades. La sustitución del hospital por la hospitalización a domicilio únicamente era asequible, viable y sostenible para la aristocracia urbana, en especial los eclesiásticos y la nobleza de mayor alcurnia, asistida en sus viviendas por un cuerpo médico capaz de ofrecer simultáneamente sus servicios a la masa y a la individualidad ${ }^{23}$.

\section{Remodelaciones y crispación en el Barrantes de la segunda mitad del siglo XVIII}

El período histórico comprendido entre 1750 y 1800 presenta, a mi entender, en su devenir diacrónico 3 etapas bien diferenciadas, cada una de las cuales estuvo marcada por la existencia de problemas estructurales, conflictos humanos y tensiones financieras y económicas contrastadas aunque complementarias y en evolución permanente. Un primer estadio, 1753-1786, con múltiples tensiones

BIFG, 215, Burgos, pp. 245-272 y MARCOS MARTíN, A. (1985): "El Hospital de San Antolín como hospital militar", en Economía, sociedad, pobreza en Castilla..., Palencia, tomo II, pp. 620-625.

22. FOUCAULT, M. (1985): "La política de la salud...", en Saber y verdad, Madrid, pp. 101-102.

23. Frente a los internamientos hospitalarios colectivos, el tratamiento médico privado e individualizado. Véase SANZ DE LA HIGUERA, F. J. (2006): "La temible f(r)actura de la muerte. Fallecer en el Burgos del Setecientos...", en Cuadernos de Investigación Histórica, 23, Madrid, pp. 251-283, (2009): "Cerebros, humores y economías en desequilibrio. Aproximación a la locura en el Burgos...", Investigaciones Históricas, 29, Valladolid, pp. 41-68 y (2010): "Aproximación a la "baja laboral" en el Setecientos. El "Punctto de Quartanario" en la Catedral de Burgos...", en Hispania Sacra, [ ], Madrid, pp. [ ] (en prensa). 
pero sin apenas obras, momento en el que se amortizaron las intervenciones de 1747-1750 y se pusieron las bases del ulterior dislocamiento finisecular. Una segunda etapa, 1787-1798, con importantes remodelaciones interiores y una afluencia arrolladora, y un tercer momento, 1799-1800, de intervenciones arquitectónicas profundas y múltiples enconos entre todos los implicados en la vida cotidiana del hospital Ilamado por el vulgo de Barrantes.

La perspectiva global aparece materializada visualmente en los gráficos que nos van a acompañar durante esta singladura temporal. El gráfico I muestra el "Alcance" del hospital de Barrantes en la segunda mitad del XVIII. Las posibilidades de actuación del mayordomo y los gestores del hospital estaban constantemente subordinadas a la cantidad de dinero que, en positivo o negativo, arrojaban los balances contables, año tras año. El gráfico II patentiza el número de estancias de soldados en Barrantes entre 1749 y 1795, datos obtenidos o bien en los protocolos notariales o bien en la propia contabilidad del Hospital. El gráfico III nos acerca al peso relativo que los ingresos procedentes de la Hacienda Real, por el abono de las estancias militares en el Hospital, tenían en la contabilidad de Barrantes. El gráfico IV contempla la evolución de la contabilidad del hospital de la Concepción en la segunda mitad del siglo XVIII. El gráfico $\vee$ y el gráfico VI nos indican el volumen de estancias de soldados en el citado hospital de Nuestra Señora de la Concepción. El gráfico VII muestra el ritmo de entradas de soldados en el Hospital del Rey, información procedente del Archivo General de Palacio (AGP). Dichas herramientas visuales nos permiten calibrar, por contraste, el sesgo que adoptó la presencia de tropas en las camas del hospital de Barrantes.

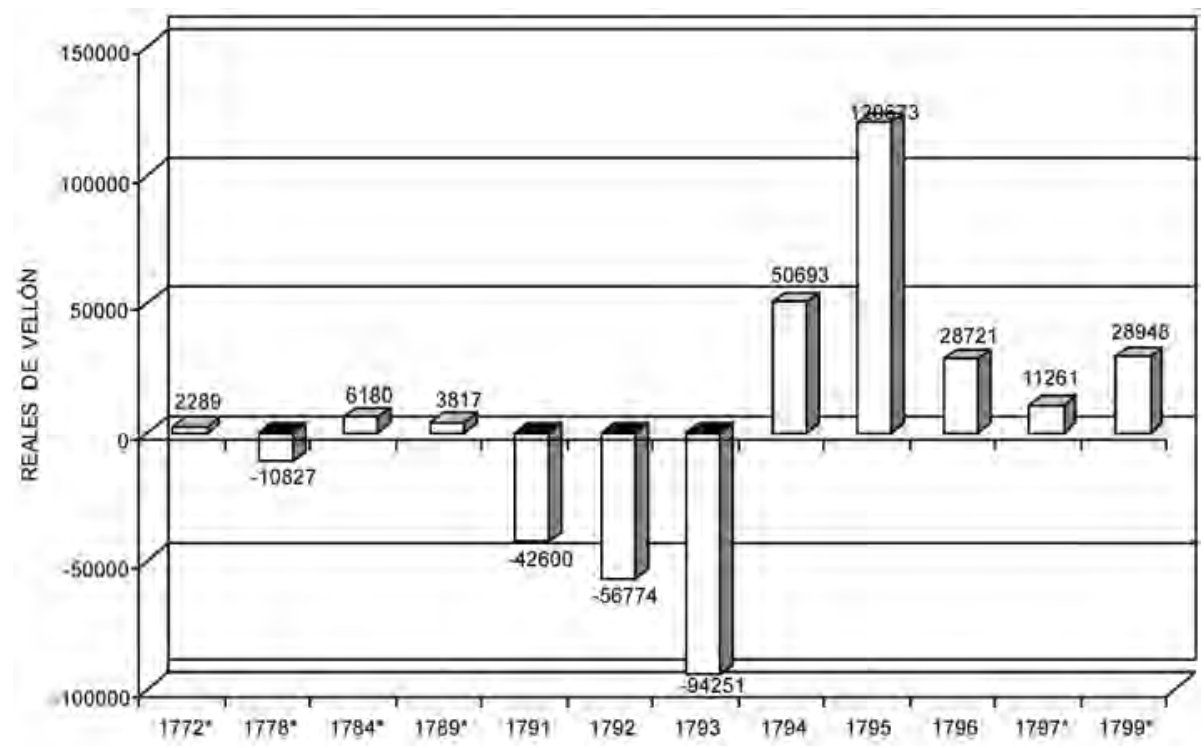

GrÁfICO I. Alcance anual en la contabilidad del hospital de Barrantes. 


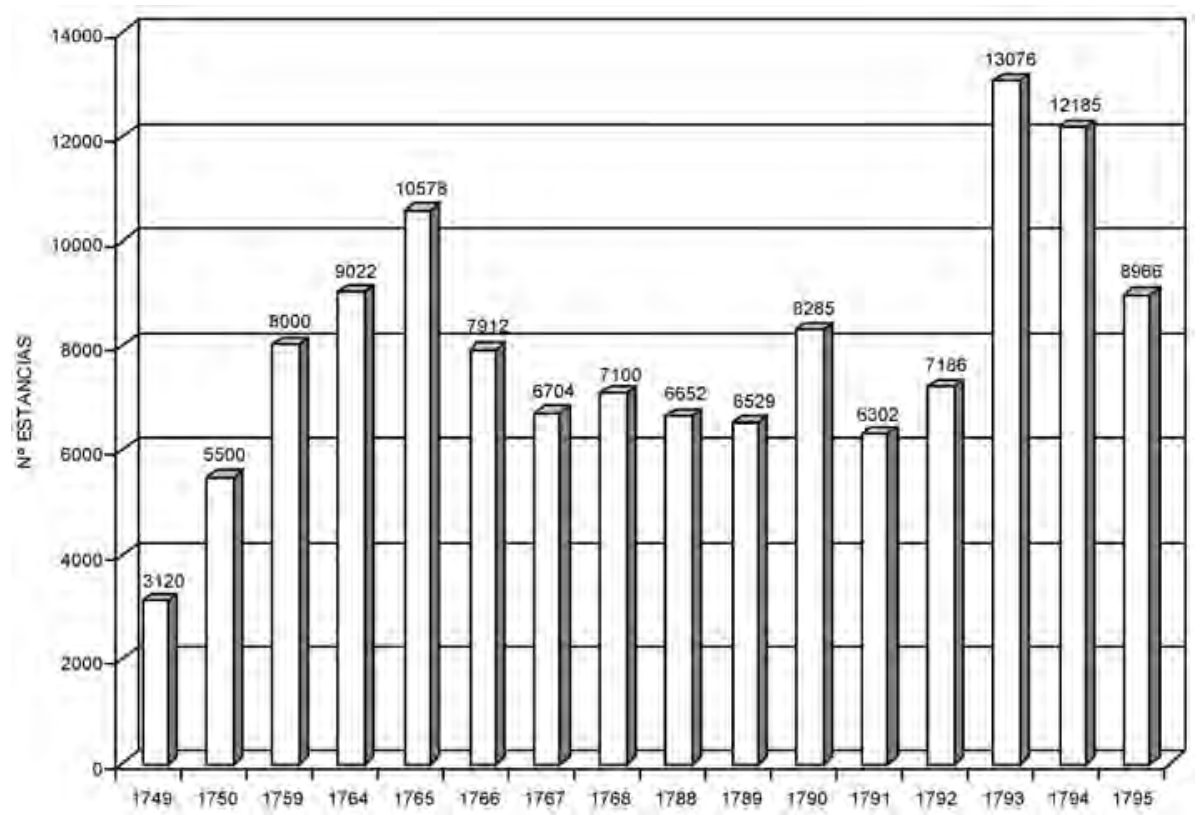

GRÁfICO II. Volumen de estancias de soldados en Barrantes.

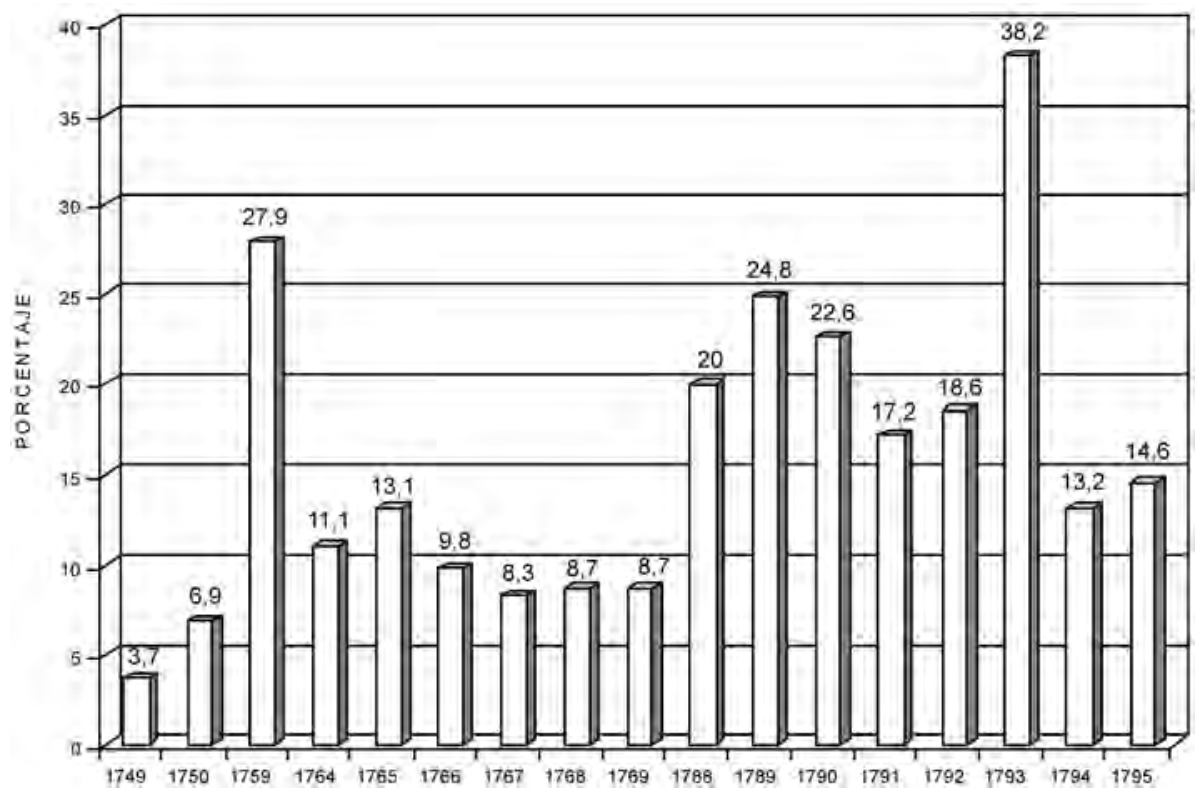

GrÁfICO III. Peso relativo de las estancias de soldados en la contabilidad del hospital de Barrantes. 
REMODELACIONES EN EL HOSPITAL DE BARRANTES (1767-1800). CABILDO, CIRUJANOS...

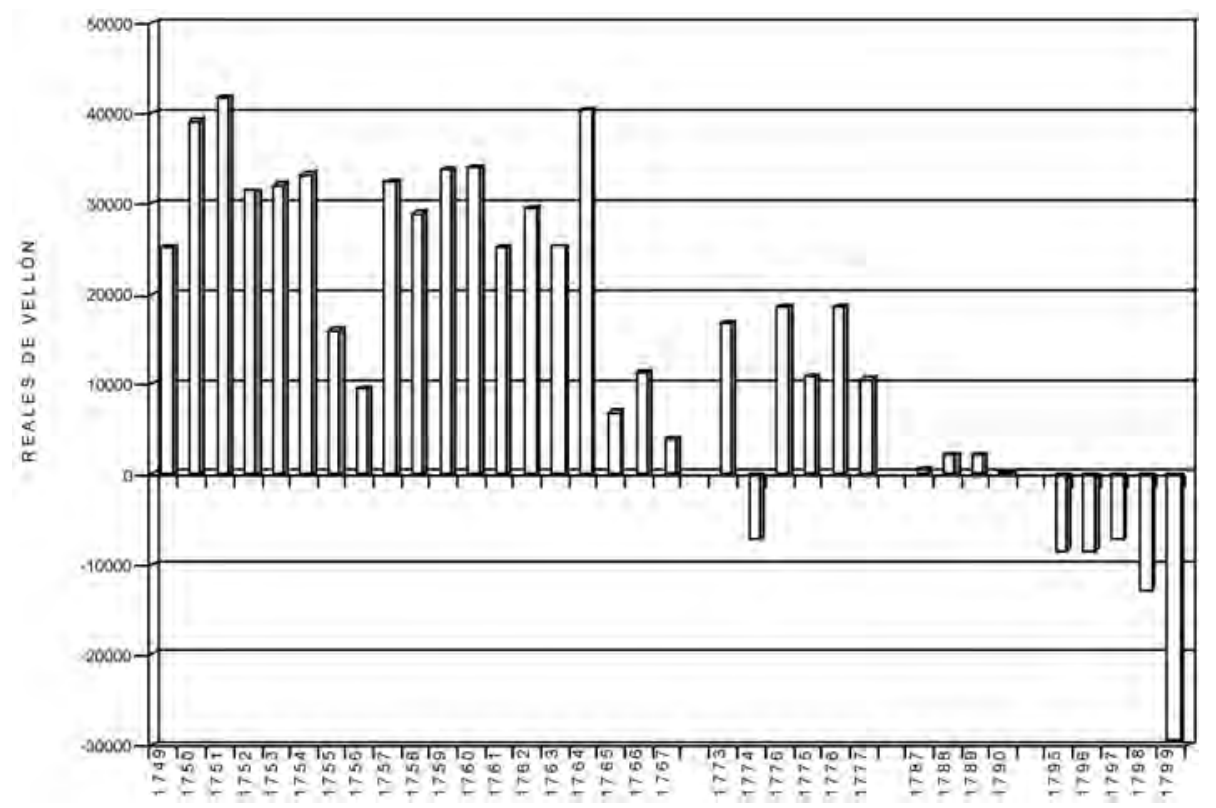

GráfICO IV. Alcance anual en la contabilidad del hospital de la Concepción.

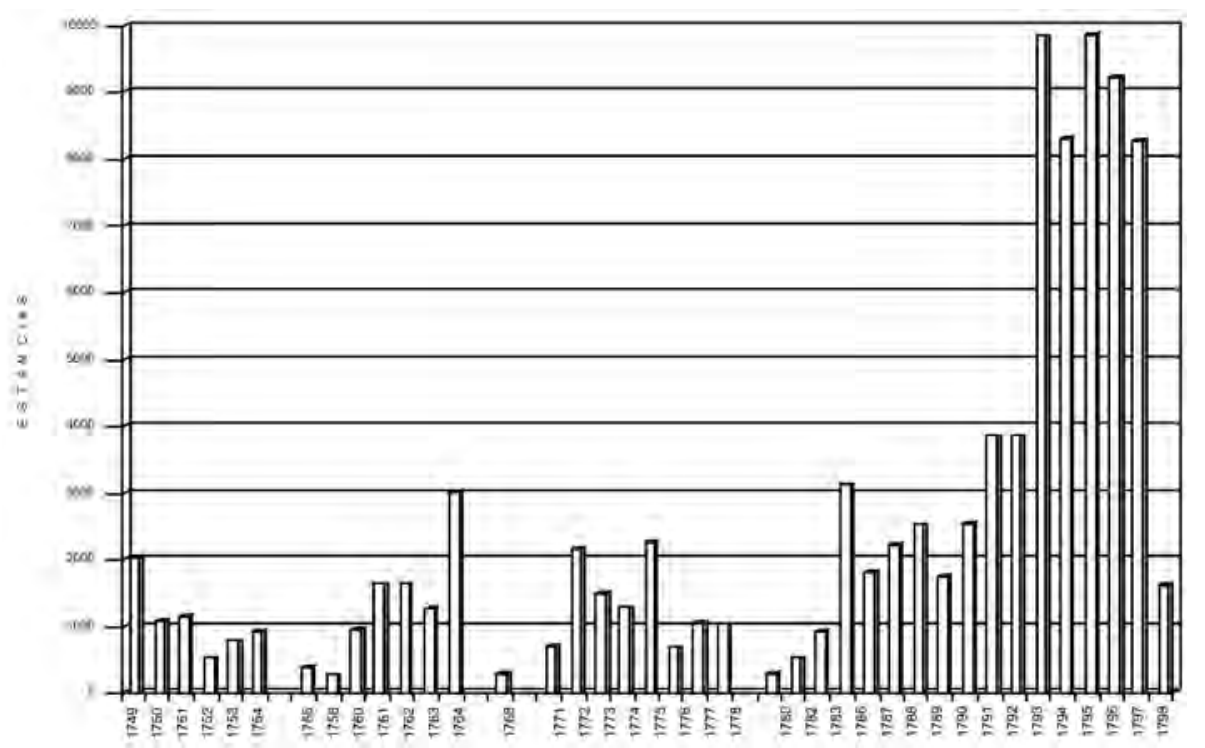

GrÁfico V. Volumen de estancias de soldados en el hospital de la Concepción. 
FRANCISCO J. SANZ DE LA HIGUERA

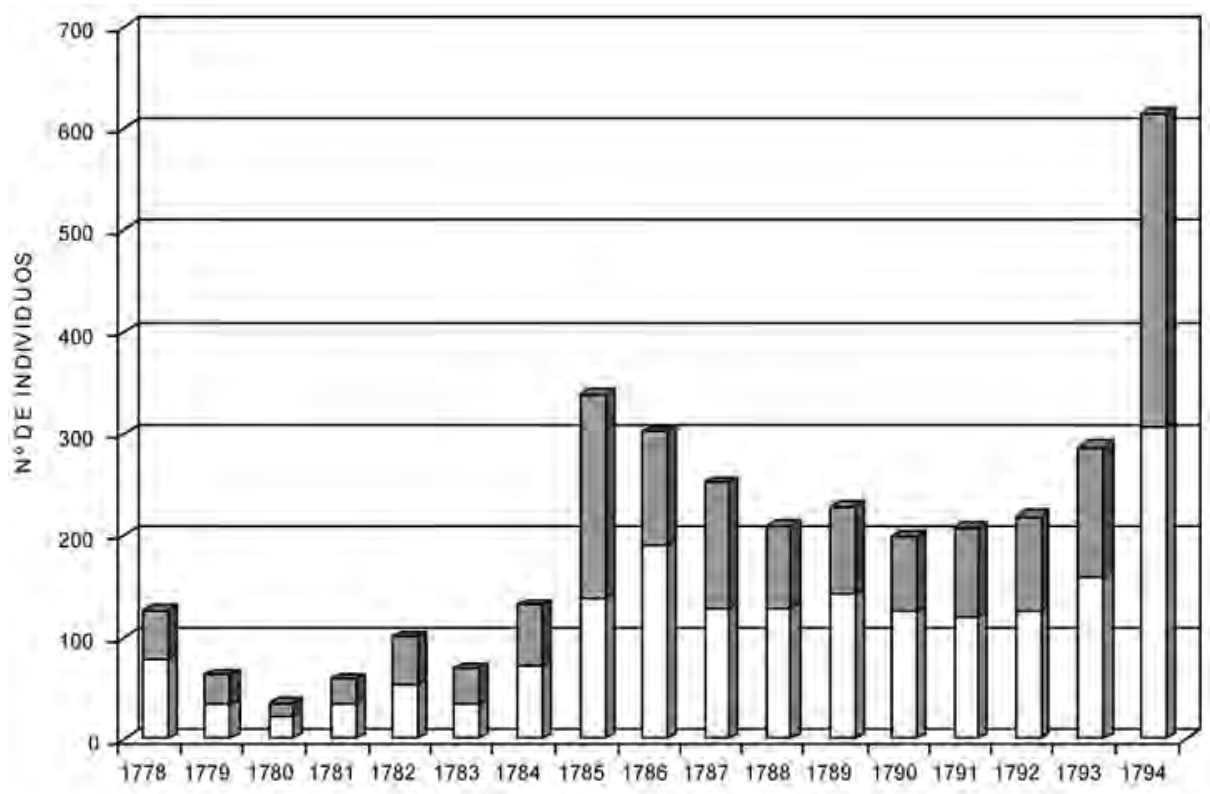

GráfICO VI. Estancias de tropas en el hospital de la Concepción.

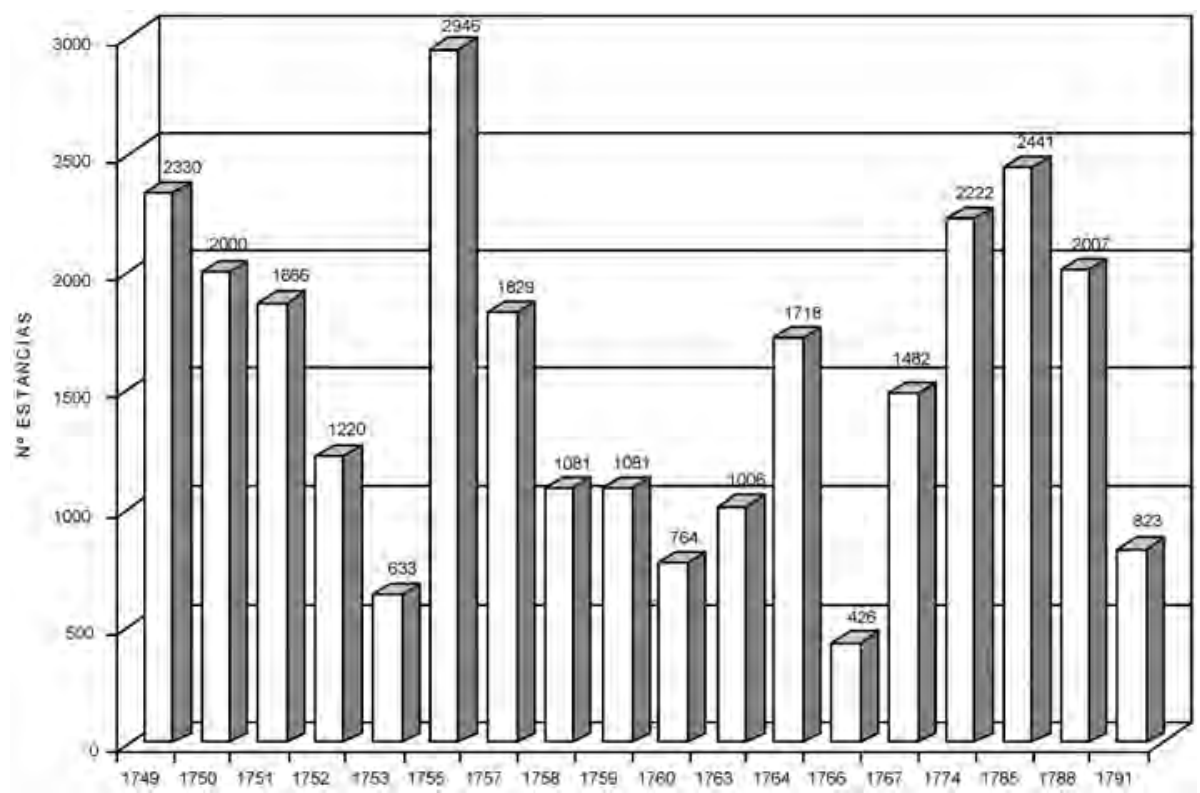

GrÁfICO VII. Estancias de soldados en el Hospital del Rey. 


\subsection{3-1786: La primera "factura" estructural de un edificio problemático}

La marcha hacia tierras de Zamora del Regimiento de Inválidos de Cataluña no supuso la desaparición de conflictos entre los gestores de Barrantes y el Cabildo catedralicio, por una parte, y las autoridades militares, por otra. Al contrario, la llegada a la ciudad castellana de nuevos Regimientos intensificó los problemas de espacio y de carácter asistencial y aceleró las certezas sobre la inadecuación del hospital a las nuevas exigencias civiles y militares. En la práctica, sea en Burgos o en Badajoz, o en el resto del territorio Ilamado España e Imperio español, "Las Instituciones benéfico-asistenciales (...) atendían las necesidades de los vecinos pobres que habitaban la ciudad, acompañados por un número significativo de militares, que confirmaban su carácter castrense" ${ }^{\prime 24}$. El devenir de los acontecimientos y las vicisitudes del hospital de Barrantes confirman este aserto $^{25}$.

En mayo de 1759, se daba cuenta de las exigencias del "Coronel del Reximiento de Ymbálidos de esta Ziudad intentaba se diese quarta Camada para sus soldados, para cuyo fin satisfaría al Hospital cada día, por cada uno, quatro reales". Se añadía, asimismo, que "avía otros del Reximiento de Lisboa que solicitaban su curación". Y aquí comienzan las disensiones, porque al citado coronel de Inválidos, "pretextando ser preferidos los suyos y nezesitar éstos orden expresa de su Majestad, (...) le parezía (...) se podía dar estar quarta camada por ahora y sin que sirviese de exemplar, pues gastándose en su cura el tiempo que regularmente se acostumbra y concurriendo con los quatro reales puede ser muy lebe el perjuizio que padezca el Hospital". La respuesta del Cabildo a las interrogantes del administrador, y las exigencias del susodicho coronel, fue numantina, de forma que "atendiendo a la mayor comodidad del Hospital, y pagando su peseta por día, gobiernen este asumpto y den la quarta Camada, sin que sirva de exemplar, con exclusión de los de Lisboa" ${ }^{26}$.

24. RODRÍGUEZ FLORES, P. (1991-1992): "Abordaje histórico a las instituciones benéfico sanitarias de la ciudad de Badajoz", en Norba, 11-12, pp. 262 (261-268). Véase también, a modo de ejemplo, las reflexiones aparecidas en ALZATE ECHEVERRI, A. M. (2008): "Militares, marineros y pobres enfermos. Contribución a la historia del hospital San Juan de Dios de Cartagena de Indias (siglo XVIII)", en Asclepio, 60/1, pp. 203-236.

25. Menos fortuna demostró, por ejemplo, el hospital de La Mejora, propiedad de la Hermandad Vieja de Ciudad Real, construido a finales del siglo XV, reparados sus desperfectos y deterioros durante el XVI y XVII y reedificado en 1742-1743. El nuevo edificio, levantado desde sus cimientos, quedó, sin embargo, deshabitado durante décadas y desprovisto de su antigua función benéfica. A fines del XVIII fue reconvertido parte del inmueble en tienda para obtener ingresos y rentabilizar las frustradas inversiones. Véase GÓMEZ VOZMEDIANO, M. F. (1991): "Caridad y asistencia social de la Santa Hermandad Vieja de Ciudad Real. Siglos XVIXVIII", en Cuadernos de Historia Moderna, 12, pp. 56 (47-65).

26. ACCB. AC. LR 106. Cabildo del 29 de mayo de 1759, folio 135. 
En diciembre de 1763, el administrador de Barrantes recibió un recado del Intendente, por medio del secretario del Ayuntamiento, "pidiendo si fuese posible que en las quadras de unciones o convalecencia, $u$ en alguna otra parte, se dispongan diez ó doce camas para soldados enfermos con calentura hasta tanto que llegue el tiempo de subministrarlas unciones por hallarse ocupados aún más de las destinadas para la tropa en los Hospitales de esta Ciudad y el de el Rey, porque la necesidad y servicio de su Majestad le obligava ha hacer esta súplica a dho Señor Addor". La situación era tan grave que el Intendente suplicaba que "las camas han de quedar desocupadas a tiempo para la curación de los gálicos", procurando "se indemnice al Hospital de los gastos que se le acrecen por la curación de los soldados" 27 . La presión sobre el espacio hospitalario era, día a día, más acuciante y se demostraba, en la práctica, que el nuevo edificio de Barrantes se estaba quedando obsoleto y, aún peor, raquítico en espacio y en servicios ambulatorios. Las estancias en Barrantes de tropas crecieron de forma acelerada -véase gráfico II-.

Si los desvelos del Regimiento de Inválidos de Cataluña fueron notables -con entre 3.000 y 5.500 estancias al año-, los quehaceres que se agolparon en el hospital de Barrantes en las décadas de los 50 y los 60 fueron apoteósicos -en 1765, 10.500 estancias, y en 1766, casi 8.000-. La décima parte de los ingresos del hospital procedían de las consignaciones remitidas por las arcas Reales -en 1759, alcanzó un hasta entonces inusitado 27,9\%-. Las cuentas de Barrantes se adornaban con tales remesas -con una ganancia, por soldado, de 6 maravedíes/día, según parece ${ }^{28}$-. Quienes no obtenían tanto placer eran los profesionales de la salud empleados en el hospital, obligados a trabajar a destajo y en condiciones cada vez más precarias, y los paisanos, que veían socavadas las atenciones que podrían recibir sin otros colectivos tan exigentes como los militares ${ }^{29}$.

El año 1767 fue especialmente dramático. Las tercianas y la sífilis acuciaban a las tropas y a las autoridades de uno y otro signo. En septiembre, los acontecimientos se precipitaron. El comisario de Guerra, que acababa de efectuar una revista de inspección al Regimiento de Caballería de Montesa, acuartelado en Burgos, exigió "que se admitan en el Hospital de Barrantes, sin dificultad, los

27. ACCB. AC. LR 108. Cabildo del 19 de diciembre de 1763, folio 506.

28. LÓPEZ GÓMEZ, J. M. (1997): "La asistencia sanitaria a militares enfermos...", en BIFG, 215, pp. 247 y 259, y MAZA ZORRILLA, Passim, pp. 177.

29. En la ciudad de Burgos era imprescindible, a todas luces, la construcción de un hospital militar como el erigido en Lugo. Véase ABEL VILELA, A. (1993): “Arquitectura militar y neoclasicismo. El cuartel de inhábiles de Lugo", en Espacio, Tiempo y Forma, Historia del Arte, 6, pp. 379-406. Véase también, a este respecto, la producción histórica de PARRILLA HERMIDA, en especial (1973): "Apuntes históricos sobre la hospitalización castrense...", en Asclepio, 25, pp. 179-252 y (1972): “Un hospital militar en 1716", en Medicina e Historia, 15, pp. 16-25 y SEGURA SALADO, J. (2002): “L'hospital militar de Palma”, en Gimbernat, 38, pp. 75-93, 
soldados de Cirujía que enviaren de dho Cuerpo y las Banderas de recluta, vaxo las Dietas establecidas, aumentando algunas Camas sino vastasen las de Constitución" ${ }^{\prime 30}$. El cómputo llevado por la Administración borbónica es escalofriante. Tenían 256 ejemplos de soldados heridos por accidentes, riñas, etcétera, con problemas para acceder a las camas de Barrantes y de cirugía, circunstancias "que suenan mal a la razón de Estado y a la Charidad y honor con que el Rey mira y quiere se trate a su tropa" ${ }^{\prime 31}$. Los 4 reales que los Reales Ejércitos le daban a los hospitales por la estancia diaria de los soldados en sus instalaciones se le iban a atragantar a Barrantes.

La misiva del comisario de Guerra le llegó al Intendente Bañuelos, quien, a su vez, remitió una carta al Cabildo catedralicio. Su contenido no ofrece dudas. “... en el quartel del Reximiento de Montesa he revistado (curándose de Cirujía) tres Soldados, de los quales dos están enfermos desde el ocho del pasado y uno desde el 21 del que acaba [agosto], por no haverlos querido admitir en el Hospital de Barrantes, pretextando su Administrador falta de Camas. Aier riñeron dos Soldados, se hirieron y ha manifestado la misma repugnancia el Administrador, y aún algún dependiente dijo que en las actuales circunstanzias no se recibirán aunque llevasen un Brazo menos, porque estando próximas las fiestas de toros y siendo regular hubiese en ellas toreros heridos era indispensable providencia preventiva de Camas, como constitutivo de la fundazión, que manda reciben por Caridad a los Pobres enfermos de Zirujía. Tan extraña es la preferencia de una Caridad contingente a una positiva (aún pagando la Real Hazienda la Hospitalidad) como irritante la expresión de anteponer el torero a el soldado del Rey, el Método de curazión y abiso de Hospital al Reximiento, es ocioso manifiestar a V. S., que produce embarazos, que, sino se acredita, perjudica al Reximiento que el soldado no tiene tan puntual asistencia como en un Hospital con detrimento de su Curazión o riesgo de su Vida. Por estas reflexiones me veo en la precisión de suplicar a V. S. tenga a bien pasar sus oficios con el Illmo Cabildo, de que depende el Administrador, para que se aumenten algunas Camas y admitan los enfermos de Zirujía"32. El Cabildo le respondió que "este Regimiento [el de Montesa] no pagaba aquí el importe de las estanzias causadas en el Hospital por los soldados de él como lo havían hecho otros y que parecía no concurrían a el de el Rey, donde tienen Quadra destinada para soldados solamente y que al presente se halla libre y desembarazada y sin enfermo alguno" ${ }^{\prime 33}$. Esta respuesta abría la caja de los truenos, dado que llevaba la problemática de la asistencia a las tropas enfermas al terreno del enfrentamiento y el encono entre los hospitales de la ciudad.

30. ACCB. AC. LR 110. Cabildo del 4 de septiembre de 1767, folio 255.

31. ACCB. AC. LR 110. Cabildo del 4 de septiembre de 1767, folio 256.

32. ACCB. AC. LR 110. Cabildo del 4 de septiembre de 1767, folios 255-259.

33. ACCB. AC. LR 110. Cabildo del 4 de septiembre de 1767, folio 259. 
Las argumentaciones del Cabildo, en su contestación a Bañuelos, nos obsequian con algunas descripciones excelentes del hospital y de su talante ante las enfermedades. "En el Hospital de Barrantes, hospital para cirujía, al presente hay dos quadras, una de hombres y otra de mujeres, compuestas cada una de 14 camas. En la de los primeros se hallan 10 paisanos y quatro soldados del Reximiento de Montesa, lo que demuestra que no hay arbitrio para admitir enfermos en ella y que no miramos con indiferencia a la tropa; además de éstas hay otras quatro piezas destinadas prezisamente para unciones y curazión de gálico y su combalezencia, que además de estar ocupadas ahora no pueden servir para Zirujía por la oposición que tienen dhas enfermedades y sus remedios con la de esta especie, de suerte que sería crueldad y un sacrificio conocido el meter en ellas a la tropa y a otros paisanos, lo que no nos permite nra estado ni la humanidad" ${ }^{34}$. No sólo se respondía a Bañuelos sino que, indirectamente, se contestaba a las insinuaciones del Comisario de Guerra, al afirmar que "quando no han alcanzado los demás hospitales de esta Ciudad para los enfermos que son de Zirujía, hemos dado orden [en Barrantes] de que en las quadras de unciones y combalezencia en los tpos en que están desocupadas se pusieran algunas camas para la tropa sin pretender utilidad alguna y contentándonos con el abono de los gastos precisos que ocasionaba este establecimiento. Estos hechos son un testimonio nada equívoco de nuestra condescendencia en este punto y si pensáramos en abandonar la intenzión de los fundadores y atender sólo a el interés del Hospital sería más útil a éste admitir los soldados que pagan que no los paisanos que nada contribuyen; pero la justicia y la Caridad nos impiden tomar partido" ${ }^{\prime 35}$.

No se allanaron, después de esta trifulca, las tensiones. El 9 de octubre de 1767, a las Actas del Cabildo catedralicio asoman, de nuevo, los "Problemas con un soldado en Barrantes" 36 . Otra carta del Intendente al Cabildo vuelve a poner en solfa a unos y otros. "Quatro días ha -sentencia Bañuelos-que por un recado attentto con uno de mis Criados pedí al Administrador del Hospital de Barrantes reciviese un Soldado del regimiento de Cantabria que se hallaba en la sensible necesidad de que le corten un dedo y me respondió que no havía Camas, pero que en vacando tendría efecto y que se previniesse con la confesión (...) Oy, con noticia de haver salido dos de Montesa, se presentó con su fe de Confesado y la baja de su Oficial y por un Platicante [sic] se le ha respondido que el Administrador no quiere y que en su Cassa nadie manda" ${ }^{37}$. Bañuelos se sintió muy dolido no sólo por las "expresiones tan opuestas a la humanidad y a la buena recíproca" cuanto por la desautorización que tales circunstancias

34. ACCB. AC. LR 110. Cabildo del 4 de septiembre de 1767, folios 257-258.

35. ACCB. AC. LR 110. Cabildo del 4 de septiembre de 1767, folio 257-258.

36. ACCB. AC. LR 110. Cabildo del 9 de octubre de 1767, folio 283.

37. ACCB. AC. LR 110. Cabildo del 9 de octubre de 1767, folios 283-284. 
generaba. Él "jamás disgustó a nadie con respuestas irritantes". Exhorta al Cabildo a que "se atienda al soldado, se le cure y el Hospital asuma sus responsabilidades" ${ }^{\prime 38}$. Unos días después, el 12 de octubre, el Cabildo afeó las peticiones del Intendente, defendió al administrador y los ministros del hospital y pidió a Bañuelos que "con tantta facilidad no se deje creer de los soldados"

1768 apaciguó los ánimos pero 1769 los exacerbó de nuevo. En enero, al Cabildo llegó otra carta del Intendente en la que se ponía en conocimiento de los eclesiásticos catedralicios la queja Ilegada a la Corte borbónica "por no haverse admitido un soldado de gálico". El subteniente Carlos Luján, del Regimiento de Infantería de Burgos, de recluta en dicha capital, elevó una queja directamente a la Corte en la que denunciaba "que en ninguno de estos Hospitales se ha querido admitir a un soldado de Vandera enfermo de gálico, teniendo obligación cada Hospital de retener ocho Camas para la tropa y estar la mayor parte desocupadas $^{\prime \prime 4}$. El recluta alemán Enrique Micker, con destino al regimiento de infantería de Murcia, fue el protagonista, quizá sin comerlo ni beberlo, de una virulenta polémica en la que uno de sus principales ingredientes era el intercambio de reproches entre los implicados, el principal de los cuales procedía del mismísimo Rey. Éste mostraba una abrumadora "repugnancia" ante el hecho de que -presuntamente- los hospitales burgaleses se negaran a admitir, para su curación, a los soldados enfermos ${ }^{41}$. El Borbón era contundente en junio de 1769: “... no hay privilexios que bastten a negar la preferencia en esta asisttencia a los milittares nezesittados en donde faltta Hospita por quentta de la Real Hacienda quando se les abona las Correspondientes esttancias, (...) que no buelva S. M. a oir que se Cierran las Puerttas de esos Hospittales para sus Soldados enfermos" ${ }^{\prime 4}$.

La carta de Muniain, Secretario del Despacho Universal de la Guerra, a los hospitales, y sus respectivos patronos -no olvidaremos que detrás de cada institución asistencial están el Concejo, el Cabildo catedralicio, el Real Monasterio de Las Huelgas y la Orden de San Benito- transmitía, por mandato del monarca, su soberana decisión "de que en lo subzesivo, no se ofrezcan en la Admisión de Soldados las Disputtas y embarazos que hastta aora han ocurrido y han Ilegado con desagrado a los oydos de S. M., que mira sus Vasallos milittares con el amor que corresponde a su propio Corazón y al intteres de que se Conserve su exércitto..." 43.

38. ACCB. AC. LR 110. Cabildo del 9 de octubre de 1767, folio 284.

39. ACCB. AC, LR 110. Cabildo del 12 de octubre de 1767, folio 290.

40. ACCB. AC. LR 111. Cabildo del 23 de enero de 1769, folio 165-166.

41. ACCB. AC. LR 111. Cabildo del 23 de enero de 1769, folio 167.

42. ACCB. AC. LR 111. Cabildo del 9 de junio de 1769, folio 254. Otro ejemplo de quejas de un coronel de un Regimiento, el de Infantería de Guadalajara, lo encontramos en SENA F. (1961): "Cosas de médicos en el Vich del siglo XVIII", en Any, 37, pp. 93 (85-94).

43. AMB. Hospital de la Concepción. HC 822 (1769) -"Real orden para que se Recivan Soldados En el Hospital de la Concepción"-, folio 3 y AGP. Patronatos. Hospital del Rey. Caja 131, Expediente 1 (5 de junio de 1769) - “Convenio entre este Hospital y los tres de la Ziudad de 
A pesar de que se restriega sistemáticamente el carácter crematístico que tiene la asistencia a las tropas, el Hospital del Rey se negó a atender al germano por graduarle de incurable; el de la Concepción por falta de camas; el de Barrantes porque no hay sala de medicina y el de San Juan, que daba en principio muestras de poder recibirle, porque se le descubrió algún grano de sarna, patología que lo catapultaba a San Julián y San Quirce, por ser contagiosa, y más si, como dijo el citado subteniente, el recluta era sifilítico ${ }^{44}$. La refriega entre los hospitales de la ciudad generó tal cúmulo de desatinos que se hubo de llegar a las amenazas, veladas y tácitas pero amenazas al fin, por parte de las autoridades borbónicas contra los gestores de los hospitales "en caso de no avenirse con exactitud a lo solicitado por el Rey" ${ }^{\prime 4}$.

El hospital de Barrantes y el Cabildo catedralicio burgalés intentaron en todo momento, de forma similar que los demás gestores hospitalarios, desmostar el "leiv motiv" de las quejas del subteniente Luján. El abad de Castro y el Doctoral capitular indicaron que "con este motibo, en el día de aier 18 de junio de 1769], se les había pasado recado por dho Señor [Bañuelos] que el Administrador se havía excusado a admitir un soldado de sarna gálica y que la queja se la dio antes de las 11 de la Mañana; y expuéstose con esta ocasión por el referido Sr Administrador que no tubo noticia de tal Soldado hasta más de las 5 de la tarde, que por accidente vajó a las Quadras y le encontró donde ellas, y que haviendo llegado a la sazón el Cirujano Monleón y manifestado al expresado soldado que necesitaba tomar las unciones, pues sino no podía curarse, le respondió que esto no lo havía de hacer y que no quería tomarlas (...) se resolbió el ningún motibo que ha havido para la referida queja..."46.

La Abadesa de Las Huelgas, por su parte, les restregó por la cara que el Hospital del Rey en 1753 ya había dispuesto, en detrimento de los enfermos paisanos y "a causa de la frecuentte concurrencia de las tropas de S. M. y su Establecimiento en dha Ciudad", (...) que en la Quadra o Salón de convaleciencia y todas sus alcobas se colocasen camas con la aplicación para curar Milittares $^{47}$, y desde entonces hastta el presentte las ha ocupado pribatibament-

Burgos, hecho en virtud de Cartta orden del Exmo Sor don Gregorio Muniain, Srio de Estado de Guerra (...) sobre los Militares enfermos que casa uno debe admitir, con distinción de enfermedades", s/f.

44. AMB. HC 822 (1769), folio 4-5 y AGP. Patronatos. Hospital del Rey, Caja 131, Exp. 1, s/f.

45. LÓPEZ GÓMEZ, J. M. (1977): "La asistencia sanitaria a militares...", en BIFG, 215, pp. 251. La política borbónica e ilustrada, tendente a fusionar instituciones hospitalarias y racionalizar su número y coste social y económico, pasaba en Burgos por una especialización de los grandes edificios disponibles en función de las patologías médicas.

46. ACCB. AC. LR 111. Cabildo del 19 de junio de 1769, folio 268.

47. El médico de Las Huelgas Juan del Río Obregón indicó en su memorial del Catastro de Ensenada (mayo de 1751) que percibía entre 250 y 390 reales/año por la asistencia a las camas para soldados inválidos del Hospital. En 1749 se aumentaron 10 camas. Archivo de la Diputación Provincial de Burgos (ADPB). Catastro de Ensenada (CE). Libro 347, folio 653. 
te, haviendo sido su concurso con la frecuencia y abundancia que manifiesta". Aceptaba "con imponderable compaciencia", según se había firmado con los otros hospitales, que se harían cargo "puntualmente de ttodos los Emfermos de Cirugía que no sean Gálicos en la espresada Quadra de anttemano asignada, y de los Sarnosos en qualquier tiempo deel año, previniendo que si no fuesen basttanttes las Camas de sus Alcobas se aumentaría una fila en medio, por no haver ottro sittio ni disposición pues a tenerla i comodidad para admitir a ttodos los Soldados enfermos de qualquier especie de dolencia..." ${ }^{\prime 4}$.

La llegada de tropas a Burgos en números inusitados hasta ese momento generó múltiples conflictos no sólo de orden público sino, sobre todo, de espacio ambulatorio y de financiación y economía cotidiana en los hospitales -véanse los gráficos que acompañan al texto-. En lo referente al soldado alemán, la susodicha Abadesa previno, según sus palabras, "que, además de la Cama en que se halla el Soldado Éttico, se ponga otra en el mismo Amorttajadero a el propio fin, por no haber otro sitio ni más capacidad en el referido Hospital, y haverse de usar de su Atrio o Pórtico para amorttajar los Difunttos con la incomodidad que se percibe, en caso de hallarse ocupado aquel Quartto, que desde el principio se desttinó a el fin propuesto, i no hai arbitrio ni disposición para fabricar otro" ${ }^{\prime 4}$.

Ante el cariz que tomó la problemática de la atención a los militares, el Cabildo de la Catedral comenzó a pensar seriamente en efectuar una ampliación de sus instalaciones hospitalarias. A finales de julio de 1769, se mandó al Administrador y Diputados de Barrantes que analizaran la renta y la contabilidad anual "para en su vista determinar si podrá disponerse la execución de otra quadra más, y asimismo se mandó que se tomen las quentas para que con toda claridad se pueda ver"50. A mediados de julio, "se cometió el informe de la renta y gasto anual que hai en él su líquido sobrante". El análisis de la contabilidad fue contundente. "... en las quentas que ha dado Dn Francisco López, Mayordomo del Hospital de San Julián y San Quirce, en los años 1754-1762, resultan de Alcance contra dho $\operatorname{Sr}($...) 85.372 Rs y $10 \mathrm{mrs}$, procedidos de la renta de Juros, Casas, Zensos y pan que tiene dho Hospital y repartidos entre los 9 años corresponde a cada uno 9.481 Rs y $10 \mathrm{mrs}$. İtem en los 3 años de 1763, 64 y 65, de que están dadas las Quentas, resulta de alcanze contra dho Francisco 27.964 Rs y 41 mrs y repartidos entre dhos 3 años corresponde a cada uno 9.321 Rs y 20 mrs (...) que reservándose la tercera parte del sobrante que hubiese, las otras dos se pueden invertir en beneficio de los Pobres con acuerdo de los Cirujanos o bien haciéndose quarta Camada o en otras forma" ${ }^{\prime \prime 1}$. Como era

48. AGP. Patronatos. Hospital del Rey. Caja 131, Expediente 1 (1769), s/f. 49. AGP. Patronatos. Hospital del Rey. Caja 131, Expediente 1 (1769), s/f.

50. ACCB. AC. LR 111. Cabildo del 26 de junio de 1769, folio 274.

51. ACCB. AC. LR 111. Cabildo del 14 de Julio de 1769, folios 290-291. 
usual, las intervenciones arquitectónicas quedaron en suspenso hasta llevarse a cabo bastantes años después.

Los problemas de Barrantes no se reducían al hacinamiento por la falta de espacio y a las angustias económicas de su administrador. En noviembre de 1772 se sumaron un conjunto de incidentes entre varios soldados y el cirujano latino Fernández Vega, titular de la Ciudad e interino en Barrantes ${ }^{52}$, que provocaron una nueva conmoción hospitalaria. Según se narra en las Actas capitulares, tres dragones indebidamente despedidos del hospital, y vueltos a admitir por la intercesión del Cabildo catedralicio, tenían auténtico miedo, pánico, por las prácticas del citado Fernández, que al sargento mayor don Pedro de Buck ${ }^{53}$ suscitaban pura y simple "repugnancia". Dichos militares exigían ser atendidos por Monleón -que fuera él "el que los cure o los mate"54-. La queja se fundamentaba en que, al parecer, el cirujano Fernández "no havía querido subministrarles medicamento alguno ni tampoco reconocerles sus males, que en el día son Purgaciones, diciéndoles que eran incurables" ${ }^{\prime \prime 5}$. Monleón aseguraba que sus patologías tenían cura y asumía "estar pronto a cuidar a los soldados galicados que concurran a dho Hospital". El doctor López Gómez ha explicado con detenimiento las razones que fundamentan tal animadversión ${ }^{56}$. Monleón no ignoraba "que siendo mucho el Número, será preciso que los Paisanos le toleren y sufran alguna falta, que con este motivo podrá ocasionarles, y que para en el caso de enfermedad o ausencia de esta Ciudad a alguna apelación convendría se tomase algún medio, pues de otro modo será perjudicarle en sus utilidades" ${ }^{\prime \prime 7}$. Aunque Fernández Vega en principio dio muestras de sentimiento y queja, y finalmente aceptó la asistencia a los paisanos de cirugía, acabó por despedirse de Barrantes. Su ausencia dio pie a la llegada de uno de los más eximios, geniales, esmerados y comprometidos cirujanos de la ciudad de Burgos en la segunda mitad del siglo XVIII ${ }^{58}$.

52. Véase LÓPEZ GÓMEZ, J. M. (1996): Cirugía ilustrada en Burgos. La figura y la obra de José Victoriano Gómez (1.773-1.819), Burgos, pp. 73-76.

53. A don Pedro Juan del Buch y Odonel, sargento mayor del Regimiento de dragones de La Reina se le puede adjudicar, en 1776, un nivel de fortuna cercana a los 350.000 reales. AHPB. PN. Nicolás Martínez de Vibanco. Legajo 7151 (6 de agosto de 1776), folios 119-122.

54. ACCB. AC. LR 112. Cabildo del 4 de noviembre de 1772, folio 396. El escribano capitular indicó, ante la brutalidad de tal exabrupto y las circunstancias concomitantes, que "bien sé que la expresión es algo escabrosa".

55. ACCB. AC. LR 112. Cabildo del 4 de noviembre de 1772, folio 396.

56. LÓPEZ GÓMEZ, J. M. (1996): Cirugía ilustrada en Burgos..., Burgos, pp. 73-76.

57. ACCB. AC. LR 112. Cabildo del 6 de noviembre de 1772, folio 401.

58. LÓPEZ GÓMEZ, J. M. (1996): Cirugía ilustrada en Burgos..., Burgos y (1999): "Los profesionales sanitarios de la ciudad de Burgos en 1740", en BIFG, 218, pp. 19-31. Véase también PALMA, F. (2008): "Cirujanos del Cabildo Catedralicio Giennense. Siglo XVIII", en Elucidario, 6, pp. 217-224; MORETÓN ALONSO, M. (1993): Las profesiones sanitarias en Castilla y León (siglo XVIII), Valladolid; CONEJO RAMILO, R. (1970): “Los cirujanos y matronas en Archidona durante la Edad Moderna", en Asclepio, 22, pp. 125-130; RIERA, J. y JIMÉNEZ MUÑOZ, J. (1973): 
En 1776 y 1777 retornaron los antiguos "fantasmas" de los enfrentamientos entre los hospitales urbanos burgaleses a tenor de las admisiones de "enfermos éticos". Todos unían, como de la peste, de los soldados tuberculosos y se resistieron de manera denodada a albergar en sus "quadras" a los soldados susceptibles de generar contagios irreparables. El compromiso del hospital de la Concepción, a finales de 1766, de disponer en todo momento de dos camas preparadas para enfermos contagiosos e incurables, rechazados en los demás hospitales, y, a la postre, de "atender en exclusiva a los soldados aquejados de enfermedades de carácter médico", desplazaba radicalmente de estos cometidos al hospital de San Juan, que probablemente no aceptó de buen grado el nuevo reparto de cometidos. Tampoco tenían sitio en Barrantes. El Intendente se convenció de ello después de una visita de reconocimiento en San Julián, donde revisó "muy por menor todas sus habitaciones y Oficinas sin omisión alguna". Hubo de admitir que era de una absoluta "imposibilidad poderse colocar en él [Barrantes] semejantes enfermos y que por lo propio procuraría en quanto estuviese de su parte coadjubar a libertarle de tales molestías" ${ }^{\prime 59}$. La defensa "numantina" del Cabildo catedralicio había convencido, al parecer, al Intendente de que era "imposible la admisión de Soldados éticos y tísicos que se presentan en dho Hospital, destinado precisamente por la fundación para Cirugía y Gálico, y en el que nunca se han admitido ni valido de Médicos, sino por incidencia. Tampoco tiene Quadras, Piezas ni Quartos para ello, pues todo está ocupado con los males de su Instituto"60. La mezcla de quienes "padecen un mal tan claramente contagioso [tuberculosis] con los enfermos de Cirugía y Gálico [sífilis]"61 no era aceptable en Barrantes y no se pagaba su obligatorie-

\footnotetext{
"Juan Louis Petit (1674-1750) y otros cirujanos extranjeros en la España del siglo XVIII", en Asclepio, 25, pp. 281-316; SÁEZ GÓMEZ, J. M. y MARSET CAMPOS, P. (1980): “Profesionales sanitarios en la Murcia del siglo XVIII. Número, evolución y distribución", en Asclepio, 32, pp. 255-271; LAFUENTE, A., PUERTO SARMIENTO, J. y CALLEJA POLGUERA, C. (1988): “Los profesionales de la sanidad tras su identidad en la llustración española", en SÁNCHEZ RON, J. M. (Ed.), Ciencia y sociedad en España: de la Ilustración a la Guerra Civil, Madrid, pp. 73-74; GRANDA JUESAS, J. M. (1990): "Médicos, cirujanos, barberos, sangradores y boticarios asturianos en el Catastro del Marqués de la Ensenada", en Boletín del Instituto de Estudios Asturianos, 133, pp. 97-110; ORTIZ GÓMEZ, T., QUESADA OCHIA, C. y ASTRAIN GALLART, M. (1995): "Profesionales de la salud en la Almería del siglo XVIII, según el Catastro de Ensenada", en Actas del II Congreso de Historia de Andalucía, Historia Moderna, Córdoba, tomo I, pp. 511-520; FERNÁNDEZ DOCTOR, A. (1997): "Médicos y cirujanos de Zaragoza en la Edad Moderna. Su número y estructura sociofamiliar", en Dynamis, 17, pp. 141-164; GRANJEL, M. (2002): "Médicos y cirujanos en Extremadura a finales del siglo XVIII", en Dynamis, 22, pp. 151-187; RODRÍGUEZ SALA, M. L., PORTILLA ROMERO, J. A. y PÉREZ ORTIZ, A. (2006): "Los cirujanos privados del siglo XVI en las ciudades de México y Puebla, representantes de una actividad ocupacional en formación", en Relaciones, 105, vol,. 27, pp. 18-58.
}

59. ACCB. AC. LR 114. Cabildo del 18 de noviembre de 1776, folio 130

60. ACCB. AC. LR 114, Cabildo del 8 de noviembre de 1776, folio 117.

61. ACCB. AC. LR 114. Cabildo del 8 de noviembre de 1776, folio 118. 
dad con dinero - con las remesas enviadas por la tesorería de Zamora como pago por las estancias de hospitalidad de los soldados acantonados en Burgos o simplemente de paso- ${ }^{62}$.

Con las "aguas" algo más calmadas, en febrero de 1783 nos topamos -merced a un "Tajo Xral y Relaciones De el clero secular y regular, Hospitales y demás que gozaban esenxion de Dros de Millones en esta Ciudad, a virtud de Breve Apostólico de la Sta Sede" - con una certificación del canónigo Administrador de Barrantes en la que señala "que todo el año mantiene dho Hospital 32 Camas de cirugía y 14 para la tropa i su curación Gálica. Que se emplean Continuamente en su asistencia 8 Ministros. Que desde el Mes de Abril, en que suelen dar principio las Camadas de Sarna y Gálico, se aumentan 40 Camas y quattro ó Cinco Ministros para su servicio asta el mes de Octubre. Que si la concurrencia de la tropa es grande se habilitan Camas de Ciruxia para que no falte Socorro al Paisanaje" ${ }^{\prime 63}$. Esta magnífica descripción de las particularidades de Barrantes trae a colación, de forma concentrada, la totalidad de las problemáticas del edificio, en lo referente a número de lechos civiles y militares, ritmo estacional de las patologías y personal contratado para la asistencia ambulatoria.

Otro de los capítulos sensibles, dialéctica e inversamente proporcional al volumen de trabajo, era la cuantía de los salarios percibidos por los cirujanos de Barrantes. Su devenir es un síntoma inequívoco del incremento, por una parte, de las exigencias profesionales y, por otra, de la inflación de precios, a veces galopante, que se sufrió sobre todo a partir de los inicios de la década de los 60. Era, en esos momentos, un clamor popular el señalar que existía una tremenda "Cortedad en el mencionado salario y el precio tan subido que tienen todas las $\operatorname{Cosas}^{\prime \prime 64}$. El devenir que se muestra en el gráfico VIII lo atestigua. Fue-

62. En la carpeta de "asuntos pendientes" se encuentra una imprescindible visita al Archivo General de Simancas (AGS), Secretaría de Guerra, Hospitales (1714-1788), legajos 24092460 y Secretaría y Superintendencia de Hacienda, Hospitales (1750-1799), legajos 681-697 y Dirección General del Tesoro, Cuentas, Tesorería General. Hospitales (1721-1820), legajos 156, documentación en la que es previsible hallar el devenir de los pagos de la tesorería de Zamora a los hospitales burgaleses por las estancias de las tropas en sus instalaciones.

63. AMB. Histórica. Arbitrios. Expediente 4-12 (1783), s/f. El Administrador de Barrantes añadía, además, que "últimamente (...) el taxo echo por V. J. en el consumo de vino tinto le parece suficiente; pero que la asignación en el Blanco es mui escasa, mediante la Celebración de 1800 misas anuales en dho Hospital y el Común y frequente uso que de él se haze para sus Indispensables Curaciones y que es Indispensable el aumento de 15 ó 20 Cántaras de dha especie".

64. ACCB. AC. LR 110. Cabildo del 18 de mayo de 1767, folio 148. Fueron múltiples las ocasiones en que los criados de la Catedral, y la población en general, pidieron aumento en los salarios y elevaron sus quejas por el incremento de la inflación. En 1799, los empleados catedralicios elevaron una quejosa súplica que resume el devenir de la segunda mitad del XVIII: “... con tan corto salario que no les subministra ni aún lo preciso para alimentarse particularmente en el tpo presente, que se han encarecido todas las Cosas más del doble y se ven precisados a que sus familias salgan a mendigar". ACCB. AC. LR 123. Cabildo del 7 de febrero de 1799, folio 5. 
ron reclamando incrementos en los emolumentos y en las gratificaciones a medida que las cargas de trabajo y la inflación de precios hacían cada vez más inviable una vida cómoda y aceptable.

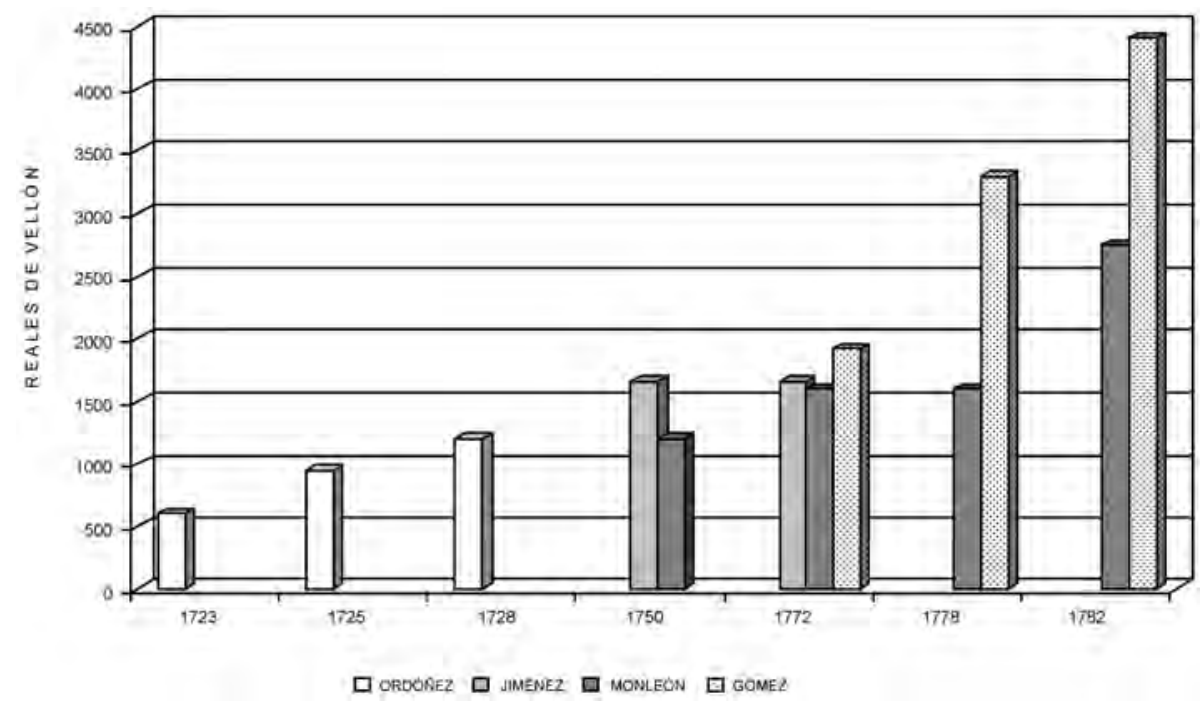

GráfICO VIII. Salarios de los cirujanos de Barrantes.

Sabemos por el Catastro de Ensenada (1751) que los dos cirujanos del hospital de San Julián y San Quirce eran, a mediados del XVIII, Domingo Jiménez ${ }^{65}$ y José Monleón ${ }^{66}$. El primero, que además era también cirujano titular de la Ciudad, percibía 1.650 reales/año ${ }^{67}$. El segundo, "cirujano examinado y graduado de latinidad", cobraba, en su calidad de "asistente como cirujano al Sto. Hospital de San Julián y Sn Quirce", a mediados de 1751, 1.200 reales/año ${ }^{68}$. Cuando en julio de

65. ADPB. CE. RP. Libro 344, folio 705.

66. ADPB. CE. RP. Libro 345, folio 299.

67. En su memorial catastral indica que su salario como cirujano titular de la Ciudad y de Barrantes "hace quatro años que no se le satisface". Percibía 100 reales/año por la asistencia al convento de San Felices, 66 reales/año en el Colegio de San Jerónimo, 8 fanegas por mitad trigo y cebada de las monjas de la Santísima Trinidad y 12 fanegas de cebada en el convento de San Agustín. A ello se añadían 8 fanegas de pan por mitad en casa de don Diego Botello y que "ganará por manos libres" 700 reales/año.

68. Monleón, cirujano examinado y graduado de latinidad, percibía como cirujano de Barrantes 1.200 reales/año, 264 reales/año en el Hospital de La Concepción, 360 reales/año en el monasterio de San Juan y "por visitas sueltas" alcanzaba a ingresar aproximadamente 300 reales/año. 
1750 se instruye el proceso de relevo del cirujano Ordóñez, fallecido en ese momento, y se contrata a Monleón, entonces cirujano de la ciudad y pretendiente a la vacante de $2^{\circ}$ cirujano dejada por Ordóñez ${ }^{69}$, los hijos de Ordóñez nos regalan, a través de las Actas capitulares, con un resumen de sus actividades y salarios. En un memorial elevado al Cabildo de la Catedral señalan que su padre comenzó sus quehaceres en Barrantes con "el oficio de segundo cirujano el $1^{\circ}$ de septiembre de 1723 con el salario de 600 reales (...) en el año 25 se le asignó por su salario la cantidad de 950 reales y en el año 281.200 reales $^{\prime \prime 7}$. La tendencia general es evidente. A más trabajo, mayores retribuciones ${ }^{71}$.

Los cirujanos del Hospital del Rey y de Las Huelgas tenían asignadas unas retribuciones similares -alrededor de los 1.650 reales/año-. Jacinto Astola percibía una ración del Hospital del Rey, que incluía vivienda y 130 reales en dinero "por la asistencia a la Sala de Inválidos que está puesta en él, que éstos se deben mirar por voluntarios respecto de la poca asistencia que puede haber, pues sólo permanecerá mientras durase dha sala de inválidos u otras determinaciones" ${ }^{\prime 72}$. Francisco García recibía, igualmente, su ración, incluidos 300 reales/año por la sala de soldados ${ }^{73}$. ¿Eran salarios suficientes y generalizados? Todos ellos suspirarían, evidentemente, por alcanzar las utilidades de, por ejem-

69. ACCB. AC. LR 106. Cabildo del 10 de julio de 1750, folio 150, Cabildo del 13 de julio de 1750, folio 152, Cabildo del 13 de julio de 1750, folio 153 y Cabildo del 31 de julio de 1750, folio 157. A la plaza de Jacinto Ordóñez concurrieron también el cirujano Santiago Villalba, a quien se computan ingresos cercanos a los 1.750 reales/año -ADPB. CE. RP. Libro 347, folio 354- y el cirujano Dionisio Diez Corcuera, casado con Josefa Ordóñez, a quien los peritos asignan un útil anual de 1.500 reales, aunque él afirmaba no percibir más que 600 a 700 reales/año en dinero y 6 fanegas de trigo de los "parroquianos" -ADPB. CE. RP. Libro 344, folio 680-. En el Burgos del siglo XVIII, todos los cirujanos eran hombres. De singular interés es, sin embargo, la lectura de DE DEMERSON, P. (1973): "Una mujer cirujano en tiempos de Carlos IV: Victoria de Félix", en Anales del Instituto de Estudios Madrileños, tomo IX, pp. 415-426.

70. ACCB. AC. LR 106. Cabildo del 31 de julio de 1750, folio 157.

71. Véanse, entre otros, los análisis de MAZA ZORRILLA, E. (1982): “Pobreza y hospitalidad...", en Investigaciones Históricas, 3, pp. 61-62; MARCOS MARTíN, A. (1985): Economía, sociedad y pobreza en Castilla..., Palencia, tomo II, pp. 554-576; CEPEDA ADÁN, J. (1965): "Estado de cuentas y reajuste de salarios a mediados del siglo XVIII del Real hospital de los Reyes Católicos de Santiago de Compostela", en Cuadernos de Estudios Gallegos, 60, p. 31-53; GRANJEL, M. (2002): "Médicos y cirujanos en Extremadura a finales del siglo XVIII", en Dynamis, 22, pp. 179-187 (151-187) y JIMÉNEZ LÓPEZ, R. (1990): “Evolución económica del hospital del Amor de Dios (Sevilla), en Archivo Hispalense, 222, pp. 41-42 (17-61).

72. ADPB. CE. RP. Libro 347, folios 656-657. La ración del Hospital del Rey incluía 1.050 reales en especies de pan, vino, carne, pescado, aceite, etc., 130 reales/año por la asistencia a la sala de inválidos, 200 reales/año por decreto de la Abadesa de Las Huelgas, de por vida, 64 fanegas de trigo y 59 reales/año por la asistencia al monasterio de Las Huelgas, 20 fanegas de trigo en Villacienzo, etcétera.

73. ADPB. CE. RP. Libro 347, folio 643. A su ración habitual en el Hospital del Rey unía 50 fanegas de trigo en el monasterio de Las Huelgas, 9 fanegas de trigo del convento de Santa Polonia y 100 reales/año de "visitas sueltas". 
plo, Santiago García, también cirujano burgalés, quien alcanzaba al año entre 3.000 y 3.500 reales $^{74}$. Lo habitual era obtener unas retribuciones cercanas a los 2.000 reales/año.

CUADRO I. Retribuciones obtenidas por los cirujanos en España.

\begin{tabular}{|c|c|c|c|c|c|c|c|c|c|c|c|}
\hline & \multicolumn{3}{|c|}{0 a 1,000 Reales } & \multicolumn{3}{|c|}{1.001 a 2.000 Reales } & \multicolumn{3}{|c|}{$>2.000$ Reales } & \multicolumn{2}{|c|}{ Total } \\
\hline Localidad & $\mathrm{N}^{0}$ & $\%$ & Promedio & $\mathrm{N}^{\circ}$ & $\%$ & Promedio & $\mathrm{N}^{\circ}$ & $\%$ & Promedio & $\mathrm{N}^{0}$ & Promedio \\
\hline BURGOS & 1 & 8.3 & 500 & 5 & 41,7 & 1.560 & 6 & 50 & 3.162 & 12 & $2,272.5$ \\
\hline ARANDA de DUERO & 1 & 25 & 500 & 2 & 50 & 1.500 & 1 & 25 & 3.000 & 4 & 1.625 \\
\hline ROA de DUERO & & & & 3 & 100 & 1.100 & & & & 3 & 1.100 \\
\hline LOGROÑO & 6. & 46.1 & 750 & 5 & 38.5 & 1.260 & 2 & 15.4 & 2.500 & 13 & 1.215 \\
\hline VALLADOLID & 16 & 29.1 & 648 & 21 & 38.2 & 1.359 & 18 & 32.7 & 2.886 & 55 & 1.652 \\
\hline SEGOVIA & & & & 1 & 7.7 & 1.100 & 12 & 92.3 & 3.616 .5 & 13 & 3.423 \\
\hline SALAMANCA & 5 & 27.8 & 820 & 6 & 33.3 & 1.133 & 7 & 38.9 & 2.971 .5 & 18 & 1761 \\
\hline LEÓN & 4 & 25 & 412.5 & 7 & 43.7 & 1.335 .5 & 5 & 31.3 & 2.840 & 16 & 1.575 \\
\hline CIUDAD RODRIGO & 1 & 25 & 500 & 2 & 50 & 1.400 & 1 & 25 & 3.300 & 4 & 1650 \\
\hline SANTANDER & & & & & & & 1 & 100 & 2.200 & 1 & 2.200 \\
\hline OVIEDO & 2 & 33.3 & 600 & 4 & 66.7 & 1.299 & & & & 6 & 1.066 \\
\hline LA CORUÑA & & & & 4 & 36.4 & 1.660 & 7 & 63.6 & 4.168 & 11 & 3.256 \\
\hline BADAJOZ & 1 & 16.7 & 550 & 2 & 33.3 & 1.266 & 3 & 50 & 2.920 & 6 & 1.973 .5 \\
\hline TOLEDO & 1 & 6.7 & 800 & 4 & 26.7 & 1.375 & 10 & 66.6 & 3.545 & 15 & 2.783 \\
\hline TALAVERA REINA & 1 & 4.5 & 550 & 19 & 86.4 & 1.129 & 2 & 91 & 2.750 & 22 & 1.250 \\
\hline CIUDAD REAL & & & & 3 & 75 & 1.100 & 1 & 25 & 2.200 & 4 & 1.375 \\
\hline GUADALAJARA & & & & & & & 3 & 100 & 3.116 .5 & 3 & 3.116 .5 \\
\hline GRANADA & 4 & 14.3 & 550 & 7 & 25 & 1.193 & 17 & 60.7 & 2.782 & 28 & 2.066 \\
\hline MÁLAGA & & & & 5 & 38.5 & 1.606 & 8 & 61.5 & 2.488 .5 & 13 & 2.149 \\
\hline ÜBEDA & & & & 3 & 100 & 1.416 .5 & & & & 3 & 1416.5 \\
\hline BAZA & & & & 1 & 100 & 1.650 & & & & 1 & 1.650 \\
\hline MURCIA & & & & 17 & 54.8 & 1.511 .5 & 14 & 45.2 & 3.190 & 31 & 2.269 .5 \\
\hline LORCA & 1. & 24 & 700 & 2 & 50 & 1.485 & 1 & 25 & 2.415 & 4 & 1.530 .5 \\
\hline TOTAL & 44 & 14.6 & 606 & 123 & 40.9 & 1.354 & 134 & 44.5 & 2.950 & 301 & 1.929 .5 \\
\hline
\end{tabular}

El cuadro I ofrece una pequeña muestra de las utilidades de los cirujanos en varias localidades de la geografía española. Descuellan en él varias acotaciones significativas. Una escueta mayoría de los cirujanos (44.5\%) obtenía un alcance anual superior a los 2.000 reales de vellón -con un promedio cercano a los 3.000 reales- . A su faga (con el $40.9 \%$ ) se situaban aquellos que lograban un útil/año de entre 1.001 y 2.000 reales -con un promedio de 1.350 reales-. El $14.6 \%$ de los cirujanos testados percibía menos de 1.000 reales -con un promedio de 606 reales/año-. Desentona, en especial, Segovia ${ }^{75}$ y son significati-

74. ADPB. CE. RP. Libro 347, folio 355.

75. GARCÍA SANZ, A. (1991): Segovia, 1753. Según las Respuestas Generales del Catastro de Ensenada, Madrid, pp. 117-118. 
vas las ocurrencias de La Coruña ${ }^{76}$, Toledo $^{77}$, Granada $^{78}$ y Málaga ${ }^{79}$, ciudades en que la mayoría (alrededor del 63\%) acumulaban unas ganancias anuales superiores a los 2.000 reales. En el extremo contrario se encuentra Logroño, caracterizada por cirujanos de muy escaso nivel adquisitivo ${ }^{80}$. En la ciudad de Burgos, con un útil promedio de 1.500 reales/año, los cirujanos de Barrantes y del Hospital del Rey se encontraban instalados en dicho sesgo, sin las carencias de los más paupérrimos y sin los excesos y las comodidades de los aristócratas. Vivían en gris, sin el negro de los desafortunados ni el rosa de quienes detentaban los mayores niveles de renta y fortuna ${ }^{81}$.

En junio de 1772, Monleón, "cirujano titular del Sto Hospital de San Julián por espacio de 22 años", solicitó que su salario de 1.200 reales -que cobraba desde 1750- fuera incrementado con urgencia. Argumentaba que "no obstante haverse las Camas de Cirugía y que también con motibo de la tropa y Real Decreto (...) en la admisión para la curazión del morbo gálico le ha sido de mayor gravamen y trabajo, ha continuado su mérito, desempeñando su obligación, cuya carga se le acrece cada día, y siendo constante que todos los bestimentos y géneros han tomado subido precio (...) no le sufraga el corto sueldo a la correspondiente manutención y decencia" ${ }^{82}$. El Cabildo, "para evitar el que molestase a V. J. con memoriales en adelante", decidió añadirle 400 reales $^{83}$. Monleón no quedó satisfecho con dicha cantidad, no sólo "en atención al duplicado trabajo por la tropa" sino que trajo a colación, por contraste, el sueldo que el Cabildo le señalaba a un recién llegado, José Victoriano Gómez ${ }^{84}$. Monleón adujo, en marzo de 1773, por una parte, "el que no tiene suficiente para mantenerse a causa de la carestía de lo comestible" y, por otra, a su extraordinaria competencia profesional, "a la especial habilidad que tiene para ope-

76. BARREIRO MALLÓN B. (1984): La Coruña, 1752. Según las Respuestas Generales del catastro de Ensenada, Madrid, pp. 132-133.

77. DONÉZAR DÍEZ DE ULZURRUN, J. M. (1990): Toledo, 1751. Según las Respuestas Generales del Catastro de Ensenada, Madrid, p. 157.

78. DOMíNGUEZ ORTIZ, A. (1990): Granada, 1752. Según las Respuestas Generales del Catastro de Ensenada, Madrid, pp. 95-96.

79. VILLAS TINOCO, S. (1995): Málaga 1753. Según las Respuestas Generales del Catastro de Ensenada, Madrid, p. 174-176.

80. ALONSO CASTROVIEJO, J. J. (1990): Logroño, 1751. Según las Respuestas Generales del Catastro de Ensenada, Madrid, pp. 94-95.

81. Las sociedades del Antiguo Régimen contienen "un puñado no pequeño de grandes ricos en un lado; la más absoluta indigencia en el otro, con el agravante de que la Real Hacienda extraía más de los cercanos al polo negro que de los alojados en el rosa". CAMARERO BULLÓN, C. (1991): "Burgos y el Catastro de Ensenada", en Historia de Burgos, III (Edad Moderna, I), Burgos, pp. 208.

82. ACCB. AC. LR 112. Cabildo del 1 de junio de 1772, folio 291.

83. ACCB. AC. LR 112. Cabildo del 26 de junio de 1772, folio 303.

84. ACCB. AC. LR 112. Cabildo del 4 de marzo de 1773, folio 485. 
raciones, sutileza y bondad de manos y caridad para con los Pobres, y que como lo acredita la experiencia el Gálico lo cura perfectamente y con mucha equidad hacia el Hospital, según resulta de las recetas despachadas para los Militares que se pagan al Boticario" ${ }^{85}$. Temeroso el Cabildo de que Monleón dejara el hospital, le añadió otros 100 reales "con la calidad de que se mantenga Cirujano de dho Hospital y no en otra forma" ${ }^{\prime \prime 6}$.

El "affaire" de Fernández Vega con los soldados -quizá parte de su mala praxis con las tropas devenía de la raquítica retribución, 600 reales/año que obtenía en Barrantes, cantidad que, en su calidad de "interino", no le estimulaba en absoluto- acabó sobrecargando más los ya de por sí extenuantes quehaceres de Monleón. El contrato del Cabildo de la Catedral con Gómez le asignaba un salario de 400 ducados/año -300 ducados como cirujano de Barrantes y 100 como cirujano del Cabildo- ${ }^{87}$. El cirujano de Briones traía, a pesar de no ser "Latino" aunque entendía latín por haber estudiado gramática, "grandes créditos (...) según informes de Sujetos de la facultad que le han tratado y de otros de honor y carácter, acreditándole todos uniformemente de las más apreciables circunstancias y habilidad, así en la Cirujía y Gálico como en la Medicina"88. El Cabildo catedralicio estaba aterrado. Cirujanos de Madrid y de Valencia había rechazado acudir a Burgos por "parecerles despreciable el de los doscientos ducados que hasta aquí ha tenido" ${ }^{\prime 89}$. Con Fernández Vega dimitido, Jiménez muy viejo y Monleón quejoso y extenuado, la delicada salud de los capitulares ${ }^{90}$ y el porvenir de los pacientes, paisanos o militares, de Barrantes estaba en entredicho. En febrero de 1773, José Victoriano Gómez fue nombrado definitivamente cirujano. Tal confirmación no estuvo exenta de polémica y, de hecho, se votó múltiples veces "y con diversidad de dictámenes". ¿Únicamente de Barrantes o también del Cabildo? Las habas, con 17 blancas y 5 negras -se habían salido fuera de la votación 3 capitulares-, ungieron a sus espaldas ambos quehaceres ${ }^{91}$.

Gómez, con la imperiosa necesidad de "conducir a su familia para domiciliarse en esta Ciudad", tensó, aún más si cabe la cuerda, al exigir al Cabildo que

85. ACCB. AC. LR 112. Cabildo del 4 de marzo de 1773, folio 485 y Cabildo del 11 de marzo de 1773 , folio 481 .

86. ACCB. AC. LR 112. Cabildo del 11 de marzo de 1773, folio 481.

87. PALMA, F. (2008): "Cirujanos del Cabildo Catedralicio Giennense. Siglo XVIII", en Elucidario, 6, pp. 217-224.

88. ACCB. AC . LR 112. Cabildo del 15 de enero de 1773, folio 461.

89. ACCB. AC. LR 112. Cabildo del 15 de enero de 1773, folio 461. El cabildo catedralicio, además, aseguraba "no hallarse sujeto de especiales circunstancias y apto para el Ministerio, y que uno parece havia en dha Corte [Madrid] (aunque no es de los de más fama) deseaba saber el salario por parecerle despreciable el de los doscientos ducados que hasta aquí ha tenido".

90. Véase SANZ DE LA HIGUERA, F. (2010): "Aproximación a la "baja laboral" en el siglo XVIII. El "Puncto de Quartanario" en la Catedral burgalesa", en Hispania Sacra, [ ] (en prensa).

91. ACCB. AC. LR 112. Cabildo del 5 de febrero de 1773, folio 471. 
se le proporcionase, a cargo de la Mesa Capitular, "una casa proporcionada en que vivir" y que se le prestara "alguna cantidad de que necesitaba para el presente para transferir su familia y muebles", fuese merced a un adelante del salario asignado o por la vía de una gratificación. El Cabildo asumió como ineludible darle "por cuenta de éste una de las casas que se ha expresado estar desocupadas o próxima a desocuparse" y hacerle llegar 3.000 reales, la mitad en un adelanto, "con la calidad de descontársela de su salario en los plazos que se convenga con dho Administrador", y la otra mitad "por modo de gratificazión, para que pueda costear el Viaje y conducir su familia y muebles" ${ }^{\prime \prime 2}$. Tales sinecuras enfadaron, y mucho, a Monleón.

En mayo de 1780, Gómez, después de 7 años de actividad profesional en Barrantes y con Monleón a las puertas de la muerte, remitió un memorial al Cabildo denunciando que su "Salario ha experimentado no serle suficiente para mantenerse con su familia en la decencia que es indispensable a un Criado de V. S. en un tiempo en que todo lo necesario a la subsistencia está a tan altos precios". Aunque él mismo significó que "es verdad que en el día soporta sus precisos gastos, es a fuerza de su industria y trabajo accesorio, que no podrá continuar Ilegando a un edad abanzada o perdiendo la salud"93. El Cabildo, saber de su "abilidad, asistencia y amor hacia los Pobres Enfermos que están a su cuidado", y, en la práctica, angustiados por las "tentaciones" que probablemente estaba ya recibiendo de otras ciudades, se rascó el bolsillo y le determinó "se le aumentasen cien Ducados más sobre los otros ciento que tiene [del Cabildo]", con la obligación, no obstante, de "atender también como cirujano a los Niños del Coro" ${ }^{\prime 94}$. Impactante hubo de ser, en ese mismo sesgo, el memorial que Monleón hizo Ilegar al Cabildo en agosto de 1780. En él exponía "que por hallarse necesitado tanto por la cortedad de su salario quanto por no haver podido trabajar a causa de haver andado indispuesto algún tiempo" pedía se le adelantaran "lo correspondiente a su salario por los quatro meses próximos venideros, con cuyo sufragio podrá remediar su necesidad"95.

En abril de 1782, José Victoriano Gómez puso a los capitulares en el brete de volver a subirle el sueldo -en la votación salieron 6 habas negras y 17 blancas $^{96}$ - . La consternación inundaba a los canónigos y al administrador de Barrantes. La villa bilbaína "solicitaba con viveza por medio de sus Diputados Síndicos Generales y otros Sujetos de la maior distinción trasladas a dha Villa a dn Josef Victoriano Gómez (...) quedándose éste [el hospital de Barrantes] en la precisión de cerrar sus Puertas y negarse al socorro de las necesidades de los

92. ACCB. AC. LR 112. Cabildo del 25 de febrero de 1773, folio 477.

93. ACCB. AC. LR 115. Cabildo del 12 de mayo de 1780, folio 518.

94. ACCB. AC. LR 115. Cabildo del 19 de mayo de 1780, folio 526.

95. ACCB. AC. LR 115. Cabildo del 14 de agosto de 1780, folio 43.

96. ACCB. AC. LR 116. Cabildo del 21 de junio de 1782, folio 458. 
Pobres que diariamente se le presentan, ya por la imposibilidad habitual de Dn Josef Monleón, ya por la escasez que generalmente se experimenta de Sujetos acreditados en esta facultad"97. En una macabra contabilidad, los emolumentos del difunto Monleón sirvieron para incrementar el salario de Gómez hasta los 400 ducados en Barrantes y dotar una nueva plaza para un "Cirujano examinado" que percibiría 150 ducados, de forma que "con ellos y el simple Cubierto de Cama, Cuarto y luz en la Cuadra y guiso en la Cozina común, estará mui bien dotado qualquiera que entre soltero y en Calidad de Practicante mayor y los Pobres asistidos a todas horas con la mayor humanidad"98. Las cábalas del Cabildo transitaban por la vía dolorosa pues "El Hospital puede sufrir esta Carga más bien que aguantar en perjuicio de la Curación de sus dolientes a Dos Cirujanos de igual Carácter que por lo general están siempre desavenidos y criar por este medio buenos facultativos para alivio suyo y del País..." ${ }^{\prime \prime 9}$. Fuera por casualidad o como consecuencia de una jugada maestra de estrategia urdida por el propio Victoriano Gómez, lo cierto es que la firma, en julio de 1782, del nuevo contrato como cirujano de Barrantes y del Cabildo y el empleo de su ayudante, colmaban todos sus deseos -al fin y al cabo, falleció en 1819, tras 46 años de ininterrumpido y fructífero servicio como cirujano titular del hospital que le acogió en 1773 y en el que trabajó gran parte de su existencia- ${ }^{100}$.

\subsection{7-1798: La sífilis salpica habitualmente a unas instalaciones obsoletas ${ }^{101}$}

En 1787 y 1788 prendió, de nuevo, en Barrantes la imperiosa necesidad de efectuar en el edificio nuevas obras que mejorasen las deficientes condiciones en que se encontraba la curación del morbo gálico. En mayo de1787, las disputas entre paisanos y soldados eran cada vez más agrias. El administrador del hospital era consciente, y con él los profesionales de la salud, de que "con motibo del mucho número de soldados que concurrían a curarse del Gálico, para que a los Pobres Paisanos que adoleciesen de este accidente no se les perjudicase, parecía preciso, siendo deel beneplácito de V.S., que en la Quadra y Convaleciencia de Mugeres se colocasen éstas y los Hombres, con la debida

97. ACCB. AC. LR 116. Cabildo del 10 de abril de 1782, folios 417-418.

98. LÓPEZ GÓMEZ, J. M. (1996): Cirugía ilustrada en Burgos..., Burgos, pp. 90.

99. ACCB. AC. LR 116. Cabildo del 10 de abril de 1782, folio 418.

100. LÓPEZ GÓMEZ, J. M. (1996): Cirugía ilustrada en Burgos..., Burgos, pp. 87-90.

101. No hemos de olvidar en ningún momento que "La sífilis era competencia del cirujano". Los médicos y la mayoría de los hospitales, en Burgos y el cualquiera otro territorio, huían de ella como de la peste. Véanse GARCÍA GUERRA, D. (1978): "La asistencia hospitalaria en la España Moderna: el Hospital Real de Santiago", en Estudios de Historia Social, 7, pp. 289327 y (1984): "La asistencia médica en el Hospital Real de Santiago al final del Antiguo Régimen", en PESET, J. L. (Coord.), Enfermedad y castigo, Madrid, pp. 287-300 y CARDONER PLANAS, A. (1974): "La orientación experimental de la cirugía en España en el siglo XVIII", en Medicina e Historia, 41, pp. 9-29. 
separación y resguardo, y permitiéndolo el concurso de aquellos, algunos de estos en su propia Quadra (...) siendo necesario como especie de quarta Camada, para que todos los Paisanos pudiesen lograr el beneficio de su curación; o que las habitaziones de los Capellanes Agonizante y Dn Santos Gutiérrez se dedicasen a este fin"102. Dos años después, en mayo de 1789, los acontecimientos seguían igual -al fin y al cabo, el Cabildo había pontificado que "se socorra a los Pobres que pueda en la misma conformidad que en iguales circunstancias se ha efectuado"103 - e incluso iban a peor.

El cirujano José Victoriano Gómez afirmaba "que ya no se curaba el Gálico como antes" y creía necesario "se quitasen las Alcobas de Convalezencias de Unziones para más ventilación"104. Esta era una problemática que se repetía, de forma similar, en prácticamente todos los hospitales, fuesen militares o eclesiástico-civiles, del territorio borbónico. Así, por ejemplo, en el hospital militar de Badajoz, modelo, como ocurría, en general, con todos los hospitales militares para los demás centros asistenciales, debido a sus mayores avances médicos, también nos topamos con un edificio deteriorado, "donde no hay suficiente ventilación, donde se detienen y malignan las emanaciones fétidas que despiden los vasos de limpieza y que se transmiten al resto del edificio y que impiden el aseo y la limpieza conveniente (...) [y] mantiene enfermos a la intemperie, al carecer de puerta"105.

El ambiente, en el interior de Barrantes, era pútrido y estaba preñado de indecencia, se temía "algún peligro de ruina del Desván" y se dudaba permanentemente qué hacer con las Convalecencias y con las alcobas ${ }^{106}$. La dubitación enervaba a los responsables del Cabildo y del hospital y, como solía ser frecuente, se acabó por solicitar al médico y los cirujanos su opinión profesional y a los maestros de obra soluciones estructurales. Además de las carencias en ventilación, otro de los problemas esenciales, común a los hospitales del Setecientos, era el hacinamiento y la limitación del espacio, de forma que "El que hai es mui pequeño, siendo la quarta parte de lo que devía ser, motivo por el que no caven en él los enfermos, que están mui mal por la extrechez"107. Era imprescindible buscar soluciones y, de hecho, esta deriva afectó no sólo a Barrantes sino también a otros muchos hospitales, de forma que, como en el Hospital Militar de La Coruña, por ejemplo, "En el último tercio del siglo XVIII

102. ACCB. AC. LR 119. Cabildo del 11 de mayo de 1787, folio 9.

103. ACCB. AC. LR 119. Cabildo del 11 de mayo de 1787, folio 9 y Cabildo del 11 de mayo de 1789 , folio 10 .

104. ACCB. AC. LR 119. Cabildo del 11 de mayo de 1789, folio 10.

105. RODRÍGUEZ FLORES, P. (1991-1992): “Abordaje histórico a las instituciones benéfico asistenciales de la ciudad de Badajoz", en Norba, 11-12, pp. 267 (261-268).

106. ACCB. AC. LR 119. Cabildo del 11 de mayo de 1789, folio 10.

107. PARRILLA HERMIDA, M. (1973): "Apuntes históricos sobre la hospitalización castrense en La Coruña. Historia de su hospital militar", en Asclepio, 25, pp. 180 (179-252). 
se efectúan algunas modificaciones en el edificio" con objeto de superar sus graves carencias y limitaciones ${ }^{108}$.

El 25 de mayo de 1787 se hizo público un memorial del médico Félix Antón y el cirujano José Victoriano Gómez en el que explicaban que "haviendo sido indispensable ocupar de enfermos Venereos, así soldados como Paisanos, las dos Saletas o Combalesciencias que hai en dho Hospital por estar Ilenas las dos Salas principales destinadas a la curación de esta enfermedad", les constaba por su experiencia cotidiana en tales ocurrencias "que la falta de ventilación en dhas Saletas espone a los enfermos a perder la vida o hacer más grande y larga su enfermedad, principalmente aquellos que entran en las Camas de seis angostas alcobas que hai en cada una de estas Combalesciencias, porque el aire que entra por la única ventana raspada que tienen al mediodía introduze los alitos pestilentes en dhas alcobas a causa de aber en algunas de ellas unos pequeños respiraderos ${ }^{\prime 109}$. Ambos estaban de acuerdo en que, para atender con éxito a la curación de los pobres enfermos, era "muy conveniente se desagan las alcobas y se dejen estas pequeñas abitaciones rasas y esentas de todo rincón donde puedan deternerse los miasmas y Vapores de los cuerpos infectos, dando asimismo alguna maior ampliación a las Viseras que hai hacia el Poniente por ser imposible darles Ventilación hacia otra parte"110.

Los maestros de obras, José de San Miguel y Pablo Antón'11, en junio de 1787, a instancias del Cabildo catedralicio y del administrador de Barrantes, hicieron un "Reconozimiento de las quadras de Combalezienzia de dho Hospital haber si tenía ho se sigia perjuizio el demoler las Alcobas", a lo que los profesionales de la construcción dijeron "no hallamos inconveniente alguno y ser muy bentajoso para el piso de Abajo por el peso que se les quita porque están fuera de Mazizo"112.

Aquietado el proceso hasta febrero de 1788, el administrador retomó el tratamiento del "affaire" de una manera agresiva. Su análisis no tiene desperdicio por lo que denuncia y sugiere. Exponía abiertamente "que por el mucho Concurso de Gentes Galicadas, así Militares como Paysanos en el año próximo, se recelaba que tal vez no se curarían como debían a causa de estar unos ya para

108. PARRILLA HERMIDA, M. (1973): “Apuntes históricos...", en Asclepio, 25, pp. 245.

109. ACCB. AC. LR 119. Cabildo del 25 de mayo de 1787, folio 16.

110. ACCB. AC. LR 119. Cabildo del 25 de mayo de 1787, folio 16. Véase CIPOLLA, C. (1993): Contra un enemigo mortal e invisible, Barcelona; CORBIN, A. (1987): El perfume o el miasma. El olfato y lo imaginario social. Siglos XVIII y XIX, Méjico y CARMONA GARCÍA, J. I. (2000): Crónica urbana del malvivir (s. XIV-XVII). Insalubridad, desamparo y hambre en Sevilla, Sevilla.

111. Véase IGLESIAS ROUCO, L. S. (1978): Arquitectura y urbanismo de Burgos bajo el reformismo ilustrado (1747-1813), Burgos, pp. 133-138.

112. ACCB. AC. LR 119. Cabildo del 18 de junio de 1787, folio 25. 
salir y otros en el babeo quando entraban varios. Por lo que, y temiéndose que sucediese no menos número de Gentes en adelante, havía pensado que [de] la havitación de el Agonizante y su circunferencia se hiciese una Sala para semejantes Urgencias"113. El sitio fue reconocido por el médico y los cirujanos que lo aprobaron y aún añadieron que "la [estancia] que tiene el otro Capellán allí cerca se destinase para el Agonizante, dándole escalera para ella, y la Ropería por el Quarto de la Anatomía por el lado que confina con las Alcobas de Quadra de Cirujía de Mugeres; o que donde la Carbonera con una Dispensa inmediata que se hallan vajo las Quadras de Unciones se hiciese una para esta Curación, lebantando algún tanto su Piso para mayor Sanidad y rasgando sus ventanas siendo necesario, en la qual se podrán acomodar con bastante desembarazo a lo menos 20 Camas, y en ese caso no hai que hechar Capellán alguno del Hospital"114. Las propuestas fueron aceptadas y se evaluó el coste en 1.500 reales poco más o menos, "los que podía soportar el Hospital". Ello significaba que uno de los capellanes, que "ha estado allí más de 21 años con especial asistencia", debía salir del interior del hospital'115. El resquemor de los clérigos afincados en Barrantes arderá con fuerza hasta los años finales del siglo, al sentirse maltratados y "ninguneados" constantemente. En las cuentas para el bienio 1789-1790 se señalan, en efecto, "Gastos en el interior del Hospital". 370 reales en 1789 y 811 reales en 1790 "en la composición de varios Quartos"

Los problemas estructurales del hospital no sólo afectaban, por tanto, únicamente a los enfermos sino que implicaban muy directamente también a los trabajadores contratados y a los clérigos que se ocupaban cotidianamente de atender a los ingresados. Los capellanes de Barrantes elevaron al Cabildo un memorial en el que denunciaban la peligrosidad de su trabajo ${ }^{117}$. Afirmaban que "...todos los Individuos y Criados que están empleados en el Servicio continuo, y aún los que por tpo limitado, de entrar para administrar las Unziones, luego que enferma alguno cuenta con total asistenzia así por lo respectivo a su manutenzión como a que le asista el Médico y Cirujano y también con las Medicinas

113. ACCB. AC. LR 119. Cabildo del 28 de febrero de 1788, folio 154.

114. ACCB. AC. LR 119. Cabildo del 28 de febrero de 1788, folio 154

115. ACCB. AC. LR 119. Cabildo del 6 de marzo de 1788, folio 159. Véase VIDAL GALACHE, F. y VIDAL GALACHE, B. (1995): "Curar el cuerpo y salvar el alma. La asistencia en el Hospital General y Pasión (1767-1850)", en Espacio, Tiempo y Forma, Historia Contemporánea, 8, pp. 33-45 y VALENZUELA CANDELARIO, J. (2004): “El insigne y suntuoso Hospital Real de Granada (II). Oficiales y sirvientes en un hospital general (1526-1535)", en Dynamis, 24, pp. 213-241.

116. ACCB. Hospital de Barrantes. Libro de cuentas (1772-1834). 1789-1790, folio 78.

117. VIDAL GALACHE, F. y VIDAL GALACHE, B. (1995): "Curar el cuerpo y salvar el alma...", en Espacio, Tiempo y Forma, Historia Contemporánea, 8, pp. 33-45. Véase, como marco general, LÓPEZ TERRADA, M. L. (1996): “El hospital como objeto histórico: los acercamientos a la historia hospitalaria", en Revista d'Història Medieval, 7, pp. 192-204. 
que necesita para su curación de la Botica de dho Hospital; y sólo los Capellanes se hallan destituidos de este alivio, viéndose precisados a valerse de Facultativos extraños, por decir los del Hospital no tienen obligación alguna de asistir más que a los ya referidos". Esta discriminación laboral les irritaba y sublevaba. Argumentaban que "no siendo de peor Calidad ni menos necesarios estos que aquellos" era el trato en Barrantes vergonzoso y más cuando eran conocedores de que en dos de los hospitales de la Ciudad "Ios primeros a quienes se contribuye con médico, Cirujano y Boticario son dhos Capellanes"118.

Las pretensiones de los capellanes quedaban sujetas a las nuevas escrituras de la botica -pendientes desde "mucho tiempo hace"- y a que el boticario que entrase asumiera la obligación de dispensar las medicinas necesarias a los capellanes. Por lo tocante a la asistencia en las enfermedades por parte de médico y cirujanos sus súplicas eran desestimadas -"no ha lugar por ahora"- y se les instaba a que volvieran a intentarlo con el ingreso de un nuevo médico o cirujano, quienes debían contemplar entre sus quehaceres el atender o no a dichos clérigos $^{119}$. Además, como se ha señalado, se les impelía a abandonar la comodidad y la cercanía a su trabajo al extender las prácticas quirúrgicas y ambulatorias a las estancias en las que tenían sus habitaciones, receptáculos de los que eran despojados en aras de cumplir fielmente con las intenciones emanadas de las mentes de los fundadores. El espacio era reducido y estaba sujeto a redistribuciones. Alguien tenía que sufrir las consecuencias del incremento de pacientes.

No menos problemáticas eran las condiciones de trabajo para los asalariados del hospital. No sólo enfermaban los cirujanos. También, los subalternos. Un ejemplo es, aunque anecdótico, muy aleccionador y paradigmático. En julio de 1793, un ministro de unciones pone en conocimiento del Cabildo su patética situación económica y profesional en Barrantes "en cuyo ejercicio hubiera seguido toda su vida sino se le hubieran fijado nueve años hace unos Dolores reumáticos en el Vientre y continuos Vómitos, efecto del mercurio introducido, y aunque en dhos nueve años ha hecho barias medicinas para su alibio y recobro de su Salud nada ha conseguido más que quedar en el último extremo de Pobreza, por lo qual se be imposibilitado para efectuar el último y único remedio que le han prescripto los Médicos, reducido a tomar las aguas minerales (...) [Por ello] suplica se digne hacerle la Caridad de Suministrarle alguna cosa para el Biaje y gastos de su Estancia (...) atendiendo a los méritos y Servicios del Suplicante"120.

118. ACCB. AC. LR 119. Cabildo del 10 de diciembre de 1787, folio 113.

119. No puede pasar inadvertida la lacerante diferencia establecida entre el clero implicado en el arduo trabajo del día a día con los enfermos de los hospitales y los capitulares catedralicios, ajenos a cualquier problemática laboral peligrosa, quienes además eran los patronos y gestores de Barrantes, aunque en la distancia. Ellos disponían de los derechos que les negaban a los demás, y no sólo al clero "proletario". Véase SANZ DE LA HIGUERA, F. J. (2010): "Aproximación a la "baja laboral" en el siglo XVIII...", en Hispania Sacra, [ ] (en prensa).

120. ACCB. AC. LR 121. Cabildo del 5 de Julio de 1793, folio 76-77. 
A mayor carga de trabajo, más camadas y más unciones, peores riesgos laborales y un más pútrido ambiente laboral. Y se avecinaba una etapa, la década de los 90, en que se iban a poner en solfa todos los niveles de extenuación y ansiedad.

Los vaticinios del administrador sobre el aumento de inquilinos del hospital no eran un asunto baladí. Barrantes, en gran parte por el prestigio de los profesionales que atendían sus "Quadras" de Cirujía y Unciones, era un establecimiento hospitalario muy conocido en el norte de España. Prueba de ello lo encontramos en las palabras de un vecino de San Vicente de la Barquera que señalaba "que por la primavera se sintió con un accidente de que le han estado curando dos Cirujanos de aquel País todo el verano y no haviendo logrado alivio le han manifestado últimamente necesita tomar las Unciones y medicamentos en los términos que se dan en el Santo Hospital de San Julián" Los facultativos certificaban que no podía esperar, sin grave riesgo de su vida, a que se le suministrasen medicinas en el año 89, a lo que se sumaba "que no se halla con medios para su curazión", circunstancias que abogaban por la gracia de ser admitido en el referido hospital lo antes posible ${ }^{121}$.

1793, con la declaración del gobierno de la Francia revolucionaria de la guerra a la España (7 de marzo), que a su vez hizo lo propio con la Convención el 23 de dicho mes, supuso un extraordinario incremento de los soldados en Barrantes, en particular -véase gráfico II-, y en la ciudad, en general -véase gráfico $\mathrm{V}$ y gráfico VI-. En Barrantes pasamos de las 7.186 estancias de 1792 a las 13.076 de 1793 y las 12.485 de 1794. Sólo en 1795 parece volverse a la senda más o menos habitual, con 8.966 estancias, cifra similar a la de 1790 $\left(8.285\right.$ estancias $^{122}$. En julio de 1791, y con un ánimo abiertamente crematístico -a pesar de la gravísima situación hospitalaria-, el Cabildo propuso al Administrador "que en atención a haverse curado en las tres Camadas del morbo gálico menos enfermos en este año que en los anteriores (...) mandase abrir la quarta Camada que en las circunstancias le parecía a dho Arnaiz muy necesaria..."123.

El informe sobre la situación de los hospitales militares en España de 1742 -según el cual seguía sin haber en Castilla y León ninguna instalación hospitalaria administrada directamente por la Real Hacienda, de modo que los soldados enfermos existentes en dicho territorio eran, como venía siendo usual, merced a los acuerdos puntuales con los hospitales, laicos o eclesiásticos, de los pueblos y ciudades, con la asignación uniforme de 4 reales por la hospitalidad de los soldados y 5 para los oficiales-, es muy probable que diera vueltas en la cabeza del teniente del Regimiento de infantería de Zamora, Ignacio Este-

121. ACCB. AC. LR 119. Cabildo del 19 de septiembre de 1788, folio 263.

122. ACCB. Hospital de Barrantes. Libros de cuentas (1772-1834).

123. ACCB. AC. LR 121. Cabildo del 14 de julio de 1794, folio 350. 
nos, "Comandante de las Armas" e Intendente del Ejército, quien elevó al Cabildo catedralicio un aguerrido memorial, en junio de 1793, cuyas palabras despiertan poderosas resonancias. Dicho oficial afirmaba que "Siendo crecido el número de Tropa que se han juntado y juntan diariamente en esta Capital con objeto de tomar unciones", son también "muchas las querellas que recibo sobre el perjuicio que les ocasiona el no admitirse en este Hospital si no los de primera gravedad por estar ocupado del Paisanaje y ningunas las Providencias que se toman en un assumptto de todo consideración", era imprescindible establecer "un Hospital Provisional con que subvenir con vrevedad a esta urgencia, así precisa en las actuales circunstancias como conveniente a ebitar la infección que con el trato libre de estas Gentes puede propagarse"124.

Era igualmente urgente "dar parte a la Superioridad para que circulando a los Regimientos el correspondiente aviso, tomen éstos la providencia de mandarlos a distintos Hospitales donde se les pueda subministrar la prompta cura". En la práctica, se estaba pidiendo la "extensión del Hospital de Sn Julián, Bulgo Barrantes" a un estatus cercano al de un hospital militar, para que "sin perjuicio de el cumplimiento de los fines de el Fundador" se permita "la curación de los Individuos deel Exercito que han concurrido y están reunidos en esta Ciudad, poseídos de humores gálicos, con la brebedad que exigen las presentes urgencias" y que "se reciban de prompto los más agrabados de esta dolencia que puedan caber en todas las oficinas y Piezas que hubiere disposición de prepararse en el pavimento del mismo Hospital, Vajo del diario premio que está establecido". Añadía el militar que era muy "combeniente por el Cirujano de él [se diese] estado de los expresados Individuos que han benido y sido conducidos a esta capital, para el beneficio de su Curación en el propio Hospital, como único destinado a el efecto"125.

El Cabildo urgió al administrador y diputados del hospital para que "dispongan la admisión en él para su curación de los soldados que hubiese arbitrio y que contesten a dho Sor Intendente (...) que mediante ser tanto el Número de Militares que se presentan y se persuade concurren a dho fin (...) no ser dable el que se les socorra su necesidad en él" y era muy conveniente "usar del medio que propone el comandante [Estenos] de acudir a la providencia para el Hospital Provisional"126. Esta respuesta no fue, en absoluto, del agrado de los responsables militares que entendían que Barrantes debía ser desalojado de paisanos y convertido en hospital militar a todos los efectos.

124. ACCB. AC. LR 121. Cabildo del 7 de junio de 1793, folios 60-61.

125. Las últimas citas textuales en ACCB. AC. LR 121. Cabildo del 7 de junio de 1793, folios $60-61$.

126. ACCB. AC. LR. 121. Cabildo del 7 de junio de 1793, folio 62. 
Prueba de ello es que, en julio de 1793, el Intendente del Ejército y Reino de Aragón y el Inspector de los Hospitales militares del Ejército de Guipúzcoa ${ }^{127}$, "haviendo dado cuenta al Rey", remitieron al Cabildo una "Solicitud" en la que, sin paliativos, exigían que "atienda a los Militares que se hallan en esa para la toma del remedio de Unziones luego que lo hayan recivido los Paisanos que ha admitido". En el fondo, se ocultaba una radical y mucho más osada propuesta, dado que se señaló que "Estando ocupados estos Hospitales de muchos enfermos que necesitavan prontamente el remedio de unciones, y no haviendo aún en este Egercito ni en el de Navarra hospital extavlecido determinadamente, como debe ser para la Guarnición, tomé por mi parte, de acuerdo con los facultativos, la providencia de que los enfermos que havia en los de mi Inspección se trasladasen a Burgos de Cuenta de la Real Hacienda, pero avisándome oy desde aquella Ciudad que ni los embiados por mi ni otros 100 del Exercito que se hallan ally al mismo fin han entrado en el Hospital porque todas las Salas están ocupadas por Paisanos entrados en todo el verano, propongo a V. S. el único recurso que hay para no exponer la salud de estos Individuos en la tardanza del remedio y evitar el dispendio que entre tanto están causando a la Real Hacienda. Será, pues, mui propio de V. S., sin perder Correo, solicite de la Superioridad una orden dirigida al Cavildo de la Sta Iglesia Metropolitana de Burgos, como patrono del Hospital de Sn Julián (Vulgo Barrantes) que mande no se admitan en él este verano más Camadas de Paisanos"128. A continuación, desatada la lengua y la mano, el conde de Campo Alange se despacha, sin escrúpulos, al afirmar que "Las Urgencias actuales, y la circunstancia de ser éstos por quienes se pide unos Individuos más necesitados y que se sacrifican en la defensa del Estado, los hace más acreedores que una porción de Vagabundos que favorecidos por la fundación suelen ocupar las Salas de aquel Hospital"129.

La respuesta del Cabildo se hizo esperar algunos días -la carta de Alange llegó el 7 de junio, escrita el 30 de mayo, y el Cabildo emitió sus consideraciones el 12 de julio-. No obstante, no tiene desperdicio y no admitía la más mínima duda. Las exigencias del Inspector de los hospitales militares del Ejército de Guipúzcoa y del Intendente del Ejército y Reino de Aragón para que se providencie "sean preferidos en la admisión del Hospital de Sn Julián, vulgo Barrantes, los soldados que se hallan en esta para la toma del remedio de Unciones" se topaba con la pura y dura realidad. El argumento del Cabildo fue contundente. "Aunque los Militares tienen y han tenido privativamente una Sala destinada a estte fin, que estaba llena quando llegaron los primeros de Guipúzcoa, haviendo sabido su llegada, dispusimos que en la segunda Camada se admitie-

127. Véase LÓPEZ GÓMEZ, J. M. (1997): "La asistencia sanitaria a militares enfermos...", en BIFG, 215, pp. 259.

128. ACCB. AC. LR 121. Cabildo del 12 de julio de 1793, folios 82-83.

129. ACCB. AC. LR 121. Cabildo del 12 de julio de 1793, folio 83. 
sen quantos soldados pudiesen ser recividos con arreglo a la fundazión del hospital, que prefiere a los Paisanos, con respecto a la concurrencia de muchos pobres enfermos que de varias partes havian venido y algunos de ellos de grabe peligro". El Administrador "destinó, además de la Sala privativa de los Soldados, otra y una Salita en que están curando treinta y cinco, dejando únicamente para los Paisanos una Sala y una Saltea, que fue el único arbitrio que halló según lo reducido del Hospital"130.

Con todo, la presión sobre Barrantes era sistemática y el objetivo final de los militares evidente. Querían Barrantes sólo para las tropas y en tal circunstancia era, para los gestores del Cabildo catedralicio, inadmisible que "se prefieran los soldados a todos los demás, porque "aunque contra la mente del Fundador se desttine todo el Hospital para la curación de los Militares y se estrechasen las Camas todo lo posible, no podrían ser bastante para [el] socorro al crecido número de los que parece ai en estta Ziudad y diariamente ban enttrando para la tercera Camada, por lo que nos parece que convendría que en Pamplona, Vittoria o en alguno de aquellos pueblos de la inmediación de la Raya [de la frontera con Francia] se pusiese algún Hospital provisional en que se curasen los que aquí no podían executarlo, logrando por este medio que no tubiesen la molestía muchos de venir enfermos tanttas leguas como hai desde la Raya de Francia a estta Ziudad y no volbiesen a recaer Ottros con tanttas Mugeres como por esttas temporadas concurren a ella con el fin de curarse y viven desarregladamente interin se les proporciona la admisión en el Hospital"131.

Las críticas sin paliativos del Cabildo a las pretensiones y permisividad de los mandos militares y a las nefastas prácticas de las tropas no hicieron mella, al parecer, en la cúpula de los Ejércitos. Prueba de ello es que el 25 de julio, se recibió carta del Comisario de Guerra en la que insistía, inquebrantable el ademán, en que "por las actuales circunstancias deben tener los Militares Enfermos de aquella frontera para la admisión al remedio de unciones el hospital de Sn Julián". Estaba convencido de que el Cabildo cumpliría con el "Serbicio al Soberano y beneficio de unos infelices que sacrifican su Salud en beneficio del Estado" y que se le avisaría cuando estuviesen "libres las Camas que ocupan los Paisanos que actualmente están curándose ${ }^{\prime 132}$.

El libro de contabilidad de Barrantes contiene noticia de 30.732 reales y 22 maravedíes "entregados al Sr Administrador para la nueba obra de Quadras executadas en él" en el bienio 1797-1798133. En junio de 1796, a pesar de los muchos problemas que ya existían para albergar a las tropas y a los paisanos

130. ACCB. AC. LR 121. Cabildo del 12 de Julio de 1793, folios 82-83.

131. ACCB. AC. LR 121. Cabildo del 12 de julio de 1793, folio 84.

132. ACCB. AC. LR 121. Cabildo del 25 de julio de 1793, folio 94.

133. ACCB. Hospital de Barrantes. Libros de Cuentas (1772-1834), folio 174. 
galicados, se planteó un encargo del Cabildo para "la fabricación de una ropería o Galería" en el interior de Barrantes, "sitio en que disponer o fabricar una ropería que sirva tanto para custodiar ropa nueva como para sacar la mojada y ventilar la de Lana para evitar la polilla". Se habían practicado diligencias con varios maestros de obra y se había llegado a la conclusión de que "el sitio más a propósito para dichos fines era fabricar una galería encima de las Quadras de zirujía"134. En las remodelaciones que tal ampliación suponía, el más castigado en esta ocasión era el mayordomo de granos y maravedíes, don Francisco Ruiz Cotorro. El Cabildo había resuelto quitarle las estancias que habitaba y separar la mayordomía de granos de la de maravedíes ${ }^{135}$.

En las Actas capitulares de octubre de 1796, se recogen las amargas palabras de Ruiz Cotorro, quien exponía, con un punto de aflicción, "haver cuidado desde el año 1762 hasta el de 72 de los efectos de dha Mayordomía sin interés y desde dho año 72, por nombramiento anual de 2.500 reales, sobre los que se dignó el Cavildo aumentarle postteriormentte 550 reales con los que a seguido en la citada Mayordomía"136. El pago que recibía a sus desvelos no estaba en consonancia con sus quehaceres administrativos, en los que, aseguraba, haber aumentado considerablemente las rentas del hospital -lamentablemente la realidad parece otra a juzgar por el devenir del gráfico I, al menos en lo tocante al período 1791-1793-. La separación de granos y maravedíes, ordenada por el Cabildo en agosto de $1796^{137}$, con la participación de 2 personas diferentes, suponía, en la práctica, una crítica furibunda del Cabildo a su gestión, una merma en sus percepciones de 1.050 reales de vellón y la pérdida de la casa. Suplicaba se le devolviera la vivienda y se retornara a los 360 ducados asignados a la mayordomía desde septiembre de 1708, "en atención a la Carestía actual de alimentos" -la inflación devoraba literalmente los salarios- y no se olvidara sus obligaciones "en los 34 años que las ha cuidado"138. En diciembre de 1796, el mayordomo de granos de Barrantes, don Manuel Francisco Ruiz Cotorro, falle-

134. ACCB. Hospital de Barrantes. Libro de Acuerdos. Actas del 6 de junio de 1796, folio 217.

135. El desalojar a los responsables de la gestión de los hospitales a finales del siglo XVIII es, al parecer, una tendencia generalizada en el territorio español. Véase, por ejemplo, las quejas del contralor y administrador del hospital militar de La Coruña, quien "por la escasez de locales carece de alojamiento en el hospital", en PARRILLA HERMIDA, M. (1973): "Apuntes históricos sobre la hospitalización castrense en La Coruña...", en Asclepio, 25, pp. 206 (179-252).

136. ACCB. Hospital de Barrantes. Libro de Acuerdos. Acta del 10 de octubre de 1796, folio 301 .

137. ACCB. AC. LR 122. Cabildo del 29 de agosto de 1796, folio 274.

138. ACCB. Hospital de Barrantes. Libro de Acuerdos. Acta del 10 de octubre de 1796, folio 302. Las "Essras de la Mayordomía del Hospital de Sn Julián y Sn Quirce" rubricadas por don Manuel Francisco Ruiz Cotorro, presbítero secretario capitular del deán y Cabildo de la Catedral de Burgos y su hermano en AHPB. PN. Alonso de Melo Peña. Legajo 7214 (29 de noviembre de 1779), folios 389-392. 
cía sin haber logrado reparar las dos injusticias que el Cabildo había cometido con él en aquel infausto año ${ }^{139}$.

En mayo de 1789, los hermanos Ruiz Cotorro habían pactado con el Cabildo una nueva escritura de Mayordomía del hospital. Persistían en el cobro de 2.500 reales/año para un período de 6 años, como era habitual, se les daba "habitación dentro de dho Hospital" y "vino libre de sisa para su consumo". En el capítulo de sus obligaciones se impone controlar la logística de las compras y ajustar al máximo los gastos y disponer de "un libro destinado para soldados [en el que] extenderá las Vajas de los que entran en el Hospital a curarse y a continuación de cada uno anotará su salida, poniendo mensualmente las estancias con separación de Reximientos y una relación gral que los abraze y de quatro en quatro meses cobrar el importe que se libre por la intendencia de Zamora" $^{140}$. Esta cláusula es completamente novedosa con respecto a escrituras anteriores y un síntoma evidente del grado de ansiedad que existía entre los responsables del Cabildo y de Barrantes sobre el volumen y efectos de la hospitalidad de las tropas. En enero de 1797 se rubricaron, por separado, las nuevas condiciones de la mayordomía de granos y en lo tocante a la mayordomía de maravedíes se advertía que "No se puede fijar el ingreso de mrs, que remite por los Alcances que se hagan al Mayordomo Económico, porque procediendo su valor principalmente de las estancias de los militares enfermos, varía según el número de soldados que acudan a curarse, pero por lo que ha resultado hace ya muchos años no se puede computar en menos de tres mil ducados anuales, los quales, aunque nos e hayan de cobrar por el mayordomo de mrs y granos, los deberá recibir y hacerse cargo en las cuentas que dé de los efectos del Hospital $^{\prime \prime 141}$. En resumen, la hospitalidad de las tropas había dislocado las expectativas y la contabilidad de Barrantes y todo era tan aleatorio y tan imprevisible que nadie sabía, a ciencia cierta, por dónde evolucionaría el estado financiero, quirúrgico, ambulatorio y humano del hospital.

La deriva de la contabilidad de Barrantes muestra, como en otras instituciones hospitalarias, una cierta tibieza en el período 1772-1789, un catastrófico y negativo balance en 1791-1793 y una sorprendente recuperación en 1794$1795^{142}$. El peso de los ingresos procedentes de la Real Hacienda, por los pagos devengados de la hospitalidad de la soldadesca en Barrantes, alcanza su máxi-

139. ACCB. Hospital de Barrantes. Libro de Acuerdos. Acta del 9 de diciembre de 1796, folio 344.

140. ACCB. AC. LR 122. Cabildo del 1 de agosto de 1796, folio 260.

141. ACCB. AC. LR 122. Cabildo del 1 de agosto de 1796, folio 260 y AHPB. PN. Alonso de Melo Peña. Legajo 7229/1 (18 febrero de 1797), folios 49-51.

142. Véase, por ejemplo, SAN MARTÍN PAYO, J. (1981): “El hospital de San Bernabé y San Antolin durante la invasión francesa", en Publicaciones de la Institución Tello Téllez de Meneses, 41, pp. 76 (73-131). 
mo histórico, con un 38.2\% del "Cargo" procedente de la Tesorería de los Ejércitos. Si tal cifra es sorprendente, el examen de los ingresos por estadía en el Hospital de San Juan de Dios de Cartagena de Indias (Nueva Granada), nos deja epatados. El 57.38\% de sus entradas monetarias procede de los soldados de infantería, mientras que un escueto $21.15 \%$ fue desembolsado por los "Pobres" y un raquítico $2.14 \%$ salió de las talegas de los "Particulares" -como era usual, las gentes adineradas pagaban las visitas del médico a su casa y los pobres y las tropas se acogían a la "vocación primigenia" de los hospitales- ${ }^{143}$.

Además de los problemas contables y de espacio físico en el interior de Barrantes, a través de las Actas capitulares accedemos, en diciembre de 1791, a otra temática esencial para cualquier institución hospitalaria. El análisis de la alimentación que consumían los enfermos y operados en Barrantes es un capítulo de singular interés para evaluar su grado de bienestar y los costes hospitalarios. El médico Prudencio Valderrama y el cirujano José Victoriano Gómez, titulares ambos del Cabildo catedralicio y de Barrantes, emitieron, por encargo del Patrono, el deán y Cabildo, un "dictamen sobre el arreglo y régimen de alimentos que se deben subministrar a los Pobres enfermos que entran a curarse en esta Casa pía"144.

143. ALZATE ECHEVERRI, A. M. (2008): "Militares, marineros y pobres enfermos. Contribución a la historia del hospital San Juan de Dios de Cartagena de Indias (siglo XVIII)", en Asclepio, 60/1, pp. 233 y 205 (203-236).

144. ACCB. AC. LR 120. Cabildo del 9 de diciembre de 1791, folio 286 (286-287). En Burgos, las relaciones entre médicos y cirujanos eran, en general, afables y no existían excesivas discutas. Véase otras opciones en QUEVEDO, E. y ZALDÚA, A. (1992): “Antecedentes de las reformas médicas del siglo XVIII y XIX en el nuevo Reino de Granada. Una polémica entre médicos y cirujanos", en LAFUENTE, A. y SALA CATALÁ, J. (Eds.), Ciencia colonial en América, pp. 192-218. Sobre alimentación y dietas en los hospitales véanse LÓPEZ GÓMEZ, J. M. (1996): Cirugía ilustrada en Burgos..., Burgos, pp. 145-152; VINCENT, B. (1975): "Consommation alimentaire en Andalousie orientale. Les achats de l'hôpital royal de Guadix, 1581-1582", en Annales ESC, 30, pp. 445; PIUZ, A. M. (1980): "L'alimentation hospitaliere à Géneve au XVIIle siècle", en Lyon et l'Europe. Hommes et sociétés, Mélanges d'histoire offerts à Richard Gascon, vol. II, Lyon, pp. 167-185; VIDAL GALACHE, B. (1992): "La terapéutica hospitalaria del siglo XVIII: dietas, drogas y otros recursos sanadores", en Asclepio, 44/2, pp. 83-127; MAZA ZORRILLA, E. (1982): "Pobreza y hospitalidad pública en la ciudad de Valladolid a mediados del siglo XVIII", en Investigaciones Históricas, 3, pp. 69-71; CARMONA GARCÍA, J. I. (1989): "Funcionamiento, personal y asistencia en un centro sanitario del Antiguo Régimen: el hospital de la Sangre de Sevilla a comienzos del siglo XVII", en Archivo Hispalense, 220, pp. 121-124; VIDAL GALACHE, F. (1992): "¿Qué hacemos con los pobres? El origen del Asilo de San Bernardino (1834)", en Espacio, Tiempo y Forma, Historia Contemporánea, 5, pp. 315-316; ALZATE ECHEVERRI, A. M. (2008): "Militares, marineros y pobres enfermos....", en Asclepio, 60/1, pp. 226-232; LÓPEZ MORA, F. (1992): Pobreza y asistencia caritativa en el Reino de Granada: Los hospitales de Jesús Nazareno, Córdoba, pp. 103-105; PASTOR ABÁIGAR, V. (2002): “Hospital de Los Arcos: su existencia y vicisitudes desde el siglo XIII al XX", en Cuadernos de etnología y etnografía de Navarra, 77, pp. 154-157 y RODRÍGUEZ FLORES, P. (1991-1992): "Abordaje histórico a las instituciones benéfico asistenciales de la ciudad de Badajoz", en Norba, 11-12, pp. 265-266. 
La primera consideración de los citados profesionales de la salud, muy meditada y tomada "de común acuerdo", se plasmó en la constatación de la necesidad ineludible de establecer "una regla constante que se derija a la mexor asistencia de los enfermos y a desterrar los abusos arbitrarios que hastta aquí se han experimentado por no haver havido método en la distribución de Raciones, según corresponde a la diferencia de enfermedades, edades y estado de los dolientes". El caos dietético de Barrantes eran tal que se daba "la misma ración (...) al paciente que al convaleciente y al Niño que al Anciano, siendo ésta tan escasa que se reduce a una libra de Carnero, repartida para tres a la Comida meridiana y quattro onzas para cenar, entendiéndose esto en crudo, que con el huevo y lo que pierde en la cocción es necesario rebajar la tercera parte quando menos, una cucharada de garbanzos y las tres octavas parttes de un pan, que se les reparte en las tres comidas de mañana, medio día y noche, añadiéndoles por desayuno, con diferencia de días, unas veces un platillo de sopa y ottras de sangre cocida o un huebo o una taza de caldo".

Valderrama y Gómez denunciaban, de esta forma, no sólo la arbitrariedad de las dietas sino también su insuficiencia -"no siendo este victus ratio suficiente para los convalencientes adultos ni regular para los que han de estar en dieta rigurosa por necesitar éstos de más caldo substancial que el que puede salir de esta escasa uniformidad de raciones de Carne"-, "el desarreglo en el réximen de los enfermos" y, en última instancia, el "mayor dispendio del Hospital, pues quanto más se dilaten las enfermedades y el recobro de las fuerzas en la convalecencia con precisión han de ocasionar mayores gastos".

La propuesta dietética del médico y el cirujano apostaba por "dividir en tres clases los alimentos: Primera: dieta rigurosa. Segunda: media ración y Tercera: ración entera, como se aprecia en todos los Hospitales bien ordenados. En el ordem de las dietas rigurosas se comprenderá el caldo, la Sopa, los huebos, chocolate, Leche o vizcochos, a juicio de los facultativos, y en esto deberán también comprenderse los alimentos extraordinarios que necesitaren los enfermos inapetentes, como arroz, berduras cocidas, cangrejos, jigote asado, menudillos de gallina, Pichón, Pollo, leche de Burra o de Cabra y demás alimentos medicinales que suelen apetecer y necesitar esta especie de enfermos ${ }^{145}$. Por

145. En el "dictamen" de Valderrama y Gómez se indica que "haciéndonos cargo de que la leche no se halla en ciertas estaciones del año, sería mui útil que el hospital mantuviese en su rebaño algunas Cabras para no carecer de este tan preciso socorro". Sobre el consumo de leche, véase SANZ de la HIGUERA, F. (2010): "Aproximación a la producción, venta y consumo de lácteos en el XVIII burgalés", en Cuadernos de Investigación Histórica, [ ] (en prensa). En el hospital de la Concepción, en esa misma época, también se detalla el consumo de leche entre los enfermos ingresados. Cfr. también, por ejemplo, PÉREZ SAMPER, M. A. (1997): "Fiesta y alimentación en la España Moderna: el banquete como imagen festiva de abundancia y refinamiento", en Espacio, Tiempo y Forma, Historia Moderna, 10, pp. 55 y SAAVEDRA FERNÁNDEZ, P. (1994): La vida cotidiana en la Galicia del Antiguo Régimen, Madrid, pp. 129-152. 
media ración "se les dará al medio día una libra de Carne entre tres y por cena un quarterón a cada uno, que es la misma ración que oy se da generalmente a todos los enfermos, y en esta olla meridiana se podrán dos onzas de garbanzos en seco para repartirlos entre tres enfermos. De pan se les dará la misma ración que hasta aquí, que se reduce a la octaba parte de un pan por la mañana, igual porción al medio día y la misma a la noche con el caldo correspondiente para que puedan migarlo en Sopa y los que necesitaren beber vino se les dará medio quartillo a comer y ottro medio a cenar. La ración entera será media libra de carnero para comer y seis onzas para cenar, regulando una onza de garbanzos en seco para cada enfermo con su taza de caldo correspondiente y la sexta parte de un pan a cada comida de desayuno, medio día y noche, medio quartillo de vino para la comida meridiana y ottro medio para la cena, y por las mañanas tendrán el mismo desayuno que queda señalado en los de media ración, con la diferencia de añadirles alguna onza más el día que tienen sopa o sangre"146.

El informe del médico y del cirujano desgranaba, a continuación, el número y contenido de las "Ollas" y el "Réximen de Unciones". Se singulariza la dieta para "Los Soldados Venereos que pagan sus estancias" que "seguirán con la misma ración que hasta aquí, que se reduce a una libra de Carnero para medio día y noche y medio pan para todo el día, una onza de garbanzos en seco para cada uno y su desayuno de sopa o caldo, como está establecido, debiendo entrar en todas estas Ollas la misma proporción de carne que corresponde a cada enfermo, tantto a los que comen como a los que estuvieren a dieta, [y] para que tomen los suficientes caldos que necesitten se aprovecharán las raciones que no coman ésttos en el guisado de las Cenas, añadiendo la porción de carnero en crudo que se considere necesario para prestar a la cocida la sustancia que ha perdido". El espíritu de optimización de los recursos económicos del hospital precisaba cumplir con minuciosidad "este método [para] que se pueda cumplir sin confusión ni dispendio del Hospital". Para ello "se hará una tabla para casa Sala, en la qual se han de recetar los alimentos por el número de las camas, del mismo modo que se hace con los medicamentos, de cuyas listas se pasará razón a la Despensa y las mismas al Libro diario de la cuenta económica". En el libro de Acuerdos del hospital, se recoge, en diciembre de 1791, un memorando "Sobre el régimen que deben observar Mayordomo y Ama en la quenta del Carnero, vino y otras cosas... (...) aspectos relativos al buen réximen y gobierno económico de este Hospital ${ }^{\prime \prime 47}$. De tales anotaciones se desprende que tanto el Cabildo Catedralicio como los propios gestores de Barrantes habían detectado graves irregularidades y fraudes en la adquisición, disposición y reparto de las materias primas, alimenticias y logísticas, del hospital. Se

146. La totalidad de las citas sobre el "dictamen" de Valderrama y Gómez en ACCB. AC. LR 120. Cabildo del 9 de diciembre de 1791, folios 286-287.

147. ACCB. Hospital de Barrantes. Libro de Acuerdos. Actas del 12 de diciembre de 1791, folios 33-35. 
insiste en el inventario de ropas, la vigilancia de los géneros de la despensa, la asistencia al romaneo de los carneros y la vigilancia del reparto de las raciones y se puso un especial énfasis en que "El Ama tendrá siempre en su poder la llave de la leña y carbón y asistirá por sí a dar lo necesario para la cocina y Quadras, encargándola particularmente el cuidado que ni se marrote ni se lleve fuera del Hospital con pretesto de limosna ni en carbón ni encendido, para lo que vajará con frequencia a la cocina y reprenderá qualquiera esceso que allí advierta, dando cuenta al Sor Administrador su es desorden notable"148. Era evidente, como lo ha sido a lo largo de toda la historia, que en Barrantes no sólo faltaba dinero sino que sobraban ladrones. El fraude y el hurto generalizado, la corrupción en las costumbres, era un ingrediente esencial en el incremento del déficit contable.

Cuadro II. Incrementos en las percepciones de los criados de Barrantes (1791).

\begin{tabular}{|c|c|c|c|c|}
\hline \multicolumn{5}{|c|}{ "Resumen del importe de los Valores antiguos y Modernos } \\
\hline \multicolumn{5}{|c|}{ de las Raciones y Salarios de los Criados del Hospital " (1791) } \\
\hline & & & & \\
\hline & & Ración antigua & Ración moderna & $\%$ Aumento \\
\hline Ama & & 1.223 Rv 32 mvds & $1.466 \mathrm{Rv} 20 \mathrm{mvds}$ & 19.8 \\
\hline \multicolumn{2}{|c|}{ Practicante $1^{\circ}$} & 1.095 Rv 22 mvds & 1.191 Rv 30 mvds & 8.8 \\
\hline $\operatorname{ld} 2^{\circ}$ & & $1.051 \mathrm{Rv} 22$ mvds & 1.147 Rv 30 mvds & 9.2 \\
\hline Cocinera & & 947 Rv 22 mvds & $1.099 \mathrm{Rv} 30 \mathrm{mvds}$ & 16.1 \\
\hline Enfermera & & 947 Rv 22 mvds & 1.063 Rv 30 mvds & 12.3 \\
\hline Enfermero & & 947 Rv 22 mvds & 1.015 Rv 30 mvds & 7.2 \\
\hline \multicolumn{2}{|c|}{ Ministro de Unciones $1^{\circ}$} & 1.371 Rv 5 mvds & 1.439 Rv 13 mvds & 4.9 \\
\hline \multicolumn{2}{|c|}{ Ministro de Id $2^{\circ}$} & $668 \mathrm{Rv} 17$ mvds & 674 Rv 4 mvds & 0.9 \\
\hline \multicolumn{2}{|c|}{ Ministra de Id $2^{a}$} & $668 \mathrm{Rv} 17 \mathrm{mvds}$ & 674 Rv 4 mvds & 0.9 \\
\hline Sachristán & & 804 Rv 20 mvds & $819 \mathrm{Rv} 6 \mathrm{muds}$ & 1.8 \\
\hline Total & & 10.395 Rv 14 mvds & 11.257 Rv 31 mvds & 8.3 \\
\hline
\end{tabular}

Las angustias financieras de Barrantes no transitaban en exclusiva por lograr una racionalización en las dietas alimenticias y el uso de los combustibles y, a la postre, evitar las "sisas" en las materias primas de la logística hospitalaria. El déficit en la contabilidad del hospital en estos años (1791-1793) no sólo es achacable al significativo incremento del gasto en combustibles -en 1789-1790 era de 6.623 reales/año, mientras que en 1791 se elevó a 10.296 reales, en 1792 a 10.953 y en 1793 a 14.345 reales/año-, como consecuencia de las perturbacio-

148. ACCB. Hospital de Barrantes. Libro de Acuerdos. Actas del 12 de diciembre de 1791, folio 35 . 
nes climáticas y el aumento de las estancias militares, y al alza en las percepciones de los cirujanos. También gravitan sobre la contabilidad hospitalaria las mejoras en las raciones percibidas por los criados del hospital -véase cuadro II-. Era a todas luces imprescindible atajar la pérdida de poder adquisitivo de los empleados del hospital, agobiados, como hemos señalado reiteradamente, por el mucho trabajo y las mermas a sus precarias economías, devenidas de la galopante inflación de precios reinante en el último cuarto del Setecientos.

\subsection{9-1800: La dislocación interna del hospital de Barrantes}

El volumen de individuos atendidos era tal que, en abril de 1799, el médico y los cirujanos pidieron, de nuevo y de forma reiterada, mejoras en la ventilación de las "Quadras" del hospital, dado que "siendo muy numerosa la concurrencia de Enfermos Venerosos que Ilegan a curarse a dho Hospital se Ilenan todas las Salas y piezas que en él hay sin reservar las de Combaleciencia [sic], de que resulta inficionarse los Enfermos y no salir también curados como debían por la falta de ventilación". En gran parte, tales circunstancias devenían de que "las Quadras son muy bajas de techo y oscuras y necesitan más capacidad en suposición de recivirse más de los treinta y siete enfermos que hace pocos años se recivían en cada camada". Los profesionales de la salud contratados en Barrantes exhortaban al Cabildo a que tomara "prontas providencias conducentes para evitar dhos perjuicios" ${ }^{\prime 149}$.

La respuesta del Cabildo, en julio de 1799, fue encargar un "Plan" al académico León Antón ${ }^{150}$ en el que se determinó "el modo más cómmodo y económico de construir en el dho Hospital dos Salas para la curación de los Pobres enfermos $^{\prime \prime 151}$. La situación financiera y contable de Barrantes no era, como hizo notar el administrador Morales, todo lo boyante que era de desear $y$, a pesar de las propuestas del Cabildo para que se efectuasen en su totalidad las obras con la mayor brevedad, el hospital de Barrantes "en la actualidad no tenía efectivo para poder continuarla" ni "tenía dinero suficiente para completarla" -véase GRÁFICO I-. Era preciso "buscar algunos medios con los que se aprontase lo suficiente para dha obra"152.

149. El hacinamiento, la podredumbre y la precariedad no eran sólo patrimonio del burgalés hospital de Barrantes. Véase las reflexiones de ACKERKENCHT, E. (1986): La médecine hospitaliere à París (1794-1848), París; CARASA SOTO, P. (1985): El sistema hospitalario español en el siglo XIX. De la asistencia benéfica al modelo sanitario actual, Valladolid y ALZATE ECHEVERRI, A. M. (2004): Saleté et ordre. Reformes sanitaires et société en Nouvelle-Grenade, 1760-1810, París.

150. IGLESIAS ROUCO, L. S. 1978): Arquitectura y urbanismo de Burgos bajo el Reformismo Ilustrado (1747-1813), Burgos, pp. 133 y PAYO HERNANZ, R. J. (2005): El artista burgalés en la época ilustrada, Burgos.

151. ACCB. AC. LR 123. Cabildo del 12 de julio de 1799, folios 73-74.

152. ACCB. AC. LR 123. Cabildo del 3 de octubre de 1800, folio 243. 
Los problemas financieros no eran privativos únicamente del hospital de Barrantes. El Cabildo catedralicio también estaba sufriendo serios contratiempos como consecuencia de los "quantiosos socorros con que ha contribuido para sostener la última guerra con la Francia, para cubrir la desnudez de los sacerdotes Emigrados ${ }^{153}$ y para aliviar a una multitud de Labradores reducidos a la miseria por el apedreo y escasez de las cosechas en los últimos años, remediándoles con crecidas porciones de granos, donadas unas y otras proporciones a precios cómodos, en medio de los Recargos y Subsidios con que ha sido preciso grabar al Esttado Eclesiástico y cuias obligaciones ha desempeñado constantemente..."154.

La contabilidad del hospital se hallaba en una situación bastante delicada -véase gráfico I-. Un informe de los señores directores de mayordomía y del administrador de Barrantes indicaba, a mediados de 1800, que la obra que se estaba ejecutando en el hospital presentaba múltiples problemas y era preciso buscar desesperadamente "los medios de proporcionar y adelantar dineros [para] que se hagan las dos Quadras nuevas en la Crujía que sirve de habitación a dho Señor Administrador y Boticario". Las limitaciones de espacio, de carácter arquitectónico, se sumaban a las carencias financieras. "Para continuarlas y perfeccionarlas, además de lo gastado hasta el día [de la fecha], podría calcularse el coste de lo que falta en 40.000 Rs, cuya cantidad había ofrecido por vía de empréstito y sin interés un Deboto con calidad de reintegro en dinero sonante hasta que el Hospital se halle en disposición de volverlo"155. A Barrantes le era imprescindible reverdecer acciones como las del canónigo Bernabé Pruneda, quien en 1730 había cedido al hospital la totalidad de sus bienes en sus últimas voluntades ${ }^{156}$. No menos notoria fue la aportación que generó el canónigo Ramón Velarde, en cuyo testamento entrega a Barrantes, y a la Concepción, "las Sávanas de Estopa y Estopilla y Colchones con Almuadas" y, después de satisfechas todas sus mandas y gastos fúnebres, nombra a la Fábrica de la Catedral y a los referidos hospitales de Barrantes y La Concepción como herederos de sus bienes, que serían repartidos "por iguales partes". Dicho canónigo era poseedor de una de las más sólidas fortunas clericales de la ciu-

153. De entre las obras que han tratado este controvertido asunto descuellan en especial SIERRA, L. (1968): "La inmigración del clero francés en España (1791-1800). Estado de la cuestión", en Hispania, 28, p. 393-421; VILLAR GARCÍA, M. B. (2007): "Los extranjeros en la España Moderna. Un campo historiográfico en expansión", en Baetica, Estudios de Arte, Geografía e Historia, 29, pp. 425-441 y SALAS AUSÉNS, J. A. (2003): "Buscando vivir en la ciudad: trayectorias de inmigrantes franceses en los siglos XVII y XVIII", en Revista de Demografía Histórica, 21/1, pp. 141-165.

154. ACCB. AC. LR 123. Cabildo del 16 de abril de 1798, folios 615-619.

155. ACCB. AC. LR 123. Cabildo del 17 de marzo de 1800, folio 255.

156. ACCB. AC. LR 106. Cabildo del 23 de abril de 1730, folio 228. 
dad en el XVIII'157. Al hospital de Barrantes le urgían, para poder sanear su contabilidad y sufragar las urgentes e imprescindibles obras de remodelación y modernización, ayudas como la recibida por el hospital de la Concepción en 1791, en que "conpadecido un deboto de que los Pobres paisanos que enferman de males incurables contagiosos no hallan acogida en los Hospitales de esta Ciudad en que solo se admiten los de enfermedades médicas curables, conforme a su instituto, ofrecía para ayuda de establecer en el mismo Hospital algunas Camas para socorro de los primeros, ciento y Cinquenta mil rs vellón de Limosna por una vez, en especie o efectos que lo valgan"158.

El informe aconsejaba que "por ahora podía suspenderse la construcción de la nueva Casa que el Cavildo tiene acordado para la habitación de dhos Administrador y Dependientes hasta que el Hospital se halle con dinero, sin desacerse de los Vales por la pérdida considerable que sufren en el día"159. El gran sacrificado era el propio administrador que se quedaba sin vivienda dentro del hospital ${ }^{160}$ en aras de "aprovecharse en dhas Quadras su habitación". Se habilitó al citado administrador y a los diputados para continuar la obra de las "Quadras", paralizada la erección de la casa nueva "hasta que las circunstancias Io permitan", y otorgar "la Essra de fianza del empréstito de los 40.000 Rs" $^{\prime 161}$. En marzo de 1800, una magnífica noticia: los testamentarios de don Fernando Pablos materializaban la limosna de 4.000 reales que en una de sus mandas había ordenado efectuar "para la continuación de la obra de dho Hospital"162.

Las peripecias financieras de Barrantes mejoraban día a día. En julio de 1800, el teniente corregidor de la Villa y Corte de Madrid aprobaba la venta de una casa en la calle de la Reina, grabada con el capital de un censo de 11.000 reales a favor del hospital de San Julián y San Quirce, cuya cantidad fue puesta inmediatamente en la Caja de Amortización y, a continuación ejecutada a favor del hospital y contra la Real Caja ${ }^{163}$. En diciembre de 1800, el administra-

157. El inventario post-mortem de este canónigo en AHPB. Justicia Municipal. José Álvarez. Legajo 987 (3 de octubre de 1786), folios 9-85. Su nivel de fortuna alcanzaba, a la hora del fallecimiento una cifra cercana a los 270.000 reales. Disponemos de un testamento en AHPB. PN. Alonso de Melo Peña. Legajo 7221 ( 26 de septiembre de 1786), folios 469-470.

158. AHPB. PN. Francisco Sanz. Legajo 7297 (29 de julio de 1791), folios 128-138. Los hospitales recibían en ocasiones jugosas aportaciones económicas de singular interés. Véase, por ejemplo, VILLANUEVA EDO, A. (2003): "Pedro de Echevarría, un mecenas del hospital de Atxuri", en Gaceta Médica de Bilbao, 100, pp. 57-67.

159. ACCB. AC. LR 123. Cabildo del 17 de marzo de 1800, folio 255.

160. Obligado a contratar, por cuenta del hospital, el alquiler de una casa en la ciudad, "que [la] ba a habitar (...) mediante de no poder vivir en él por ahora". ACCB. AC. LR 123. Cabildo del 17 de marzo de 1800, folio 255.

161. ACCB. AC. LR 123. Cabildo del 17 de marzo de 1800, folio 255.

162. ACCB. AC. LR 123. Cabildo del 31 de marzo de 1800, folio 268.

163. ACCB. AC. LR 123. Cabildo del 21 de julio de 1800, folio 329. 
dor anunció la conclusión de las obras en las "Quadras" nuevas "a excepción de algún otro reparo de poca consideración y Costo". Era preciso, a la postre, ajustar "las Cuentas de lo gastado en dha obra hasta el día", reconocer lo que se había gastado, lo que debe el hospital, el estado de sus fondos y deliberar sobre "el Número de enfermos que se podrá recibir"164. No tardó mucho en complicarse de nuevo la asistencia ambulatoria. En mayo de 1801 el deán y el administrador anunciaban "haver entrado en él a curarse hasta sesenta soldados franceses por cuenta del Rey"165. Eran ingresos complementarios pero reiniciaban los conflictos por la ocupación del espacio interior del hospital y elevaban la "temperatura" de las relaciones humanas entre profesionales sanitarios, enfermos militares, pacientes civiles y gestores del establecimiento.

164. ACCB. AC. LR 123. Cabildo del 19 de diciembre de 1800, folio 447.

165. ACCB. AC. LR 1234. Cabildo del 4 de mayo de 1801, folios 535-536. 